\title{
Do Judges Make Regulatory Policy? An Empirical Investigation of 'Chevron'
}

\section{Citation}

Cass R. Sunstein, Do Judges Make Regulatory Policy? An Empirical Investigation of Chevron, 73 U. Chi. L. Rev. 823 (2006)

\section{Published Version}

https://lawreview.uchicago.edu/page/vol-73-issue-3-summer-2006

\section{Permanent link}

http://nrs.harvard.edu/urn-3:HUL.InstRepos:12786004

\section{Terms of Use}

This article was downloaded from Harvard University's DASH repository, and is made available under the terms and conditions applicable to Other Posted Material, as set forth at http:// nrs.harvard.edu/urn-3:HUL.InstRepos:dash.current.terms-of-use\#LAA

\section{Share Your Story}

The Harvard community has made this article openly available.

Please share how this access benefits you. Submit a story.

Accessibility 


\title{
The University of Chicago Law Review
}

\author{
Volume 73 \\ Summer 2006 \\ (C) 2006 by The University of Chicago

\section{Do Judges Make Regulatory Policy? An Empirical Investigation of Chevron}

Number 3

\author{
Thomas J. Miles $\dagger \&$ Cass R. Sunstein $\dagger \dagger$
}

\begin{abstract}
In the past quarter century, the Supreme Court has legitimated agency authority to interpret regulatory legislation, above all in Chevron U.S.A., Inc v Natural Resources Defense Council, Inc, the most cited case in modern public law. Chevron recognizes that the resolution of statutory ambiguities often requires judgments of policy; its call for judicial deference to reasonable interpretations was widely expected to have eliminated the role of policy judgments in judicial review of agency interpretations of law. But this expectation has not been realized. On the Supreme Court, conservative justices vote to validate agency decisions less often than liberal justices. Moreover, the most conservative members of the Supreme Court show significantly increased validation of agency interpretations after President Bush succeeded President Clinton, and the least conservative members of the Court show significantly decreased validation rates in the same period. In a similar vein, the most conservative members of the Court are less likely to validate liberal agency interpretations than conservative ones, and the least conservative members of the Court show the opposite pattern.

Similar patterns can be found on federal appellate courts. In lower court decisions involving the EPA and the NLRB from 1990 to 2004, Republican appointees demonstrated a greater willingness to invalidate liberal agency decisions and those of Democratic administrations. These differences are greatly amplified when Republican appointees sit with two Republican appointees and when Democratic appointees sit with two Democratic appointees.
\end{abstract}

$\dagger$ Assistant Professor of Law, The University of Chicago Law School.

$\dagger \dagger$ Karl N. Llewellyn Distinguished Service Professor, Law School and Department of Political Science, The University of Chicago. We are grateful to Adrian Vermeule for many discussions, to Einer Elhague, Jacob E. Gersen, Bert Huang, and J.J. Prescott for excellent comments, and to participants in legal theory workshops at The University of Chicago Law School, The University of Chicago Graduate School of Business, Harvard Law School, and Yale Law School. Excellent research assistance, originally compiling the extensive data analyzed here, was provided by Andres Sawicki, Cristina I. Miller-Ojeda, Anne Pogue, and Ken Merber. Special thanks for Margaret Schilt and the staff of The University of Chicago Law School Library for great help in obtaining the cases analyzed here. This Article was produced as part of the Chicago Judges Project, and we are grateful to Dean Saul Levmore for financial support. 


\section{INTRODUCTION}

More than twenty years ago, the Supreme Court decided Chevron U.S.A., Inc v Natural Resources Defense Council, Inc, one of the most important rulings in the past quarter century in American public law. Chevron famously established a two-step inquiry for courts to follow in reviewing agency interpretations of law. The first step asks "whether Congress has directly spoken to the precise question at issue," an inquiry that requires an assessment of whether Congress's intent "is clear" and "unambiguously expressed." The second step asks whether the agency's interpretation is "permissible," which is to say reasonable in light of the underlying law.

This two-step approach appears to call for a large degree of judicial deference to agency interpretations, and indeed an early study found that the Chevron decision significantly increased the rate of judicial deference. ${ }^{6}$ For its defenders, Chevron signaled a healthy awareness that the resolution of ambiguities calls for judgments of policy-and an accompanying belief that such judgments should be made by political actors, not by the federal judiciary. An additional advantage of the Chevron approach is its potential to reduce variation within federal courts of appeals through its simple instruction that courts should uphold all reasonable interpretations of ambiguous terms. $^{8}$ In light of that instruction, different courts of appeals should usually reach the same result, permitting agency interpretations so long as they are reasonable. And indeed, the leading treatise on the topic offers this bold assessment: "Chevron has reduced significantly the problem of inconsistent interpretations of agency-administered national

1467 US 837 (1984).

2 As a sign of Chevron's influence, consider the fact that the decision was cited 2,414 times in its first decade (between 1984 and January 1, 1994), 2,584 times in its next six years (between January 1, 1994, and January 1,2000), and 2,235 times in its next five years (between January 1, 2000, and January 28, 2005). LEXIS search, Mar 2006.

3 See 467 US at $842-44$.

4 Id at $842-43$.

5 Id at 843-44.

6 See Peter H. Schuck and E. Donald Elliott, To the Chevron Station: An Empirical Study of Federal Administrative Law, 1990 Duke L J 984, 1057-59 (noting that circuit courts affirmed agency decisions at a higher rate after Chevron was decided than before).

7 See Richard J. Pierce, Jr., 1 Administrative Law Treatise § 3.2-3.4 at 141-48 (Aspen 4th ed 2002) ("The Chevron Court did criticize, however, and held unlawful, substitution of judicial policy preferences for agency policy preferences where Congress intended to delegate policymaking to an agency.").

8 See Peter L. Strauss, One Hundred Fifty Cases per Year: Some Implications of the Supreme Court's Limited Resources for Judicial Review of Agency Action, 87 Colum L Rev 1093, 1121-22 (1987) (arguing that "the Chevron rule subdues this diversity [of interpretation of ambiguous statutes by the various circuits], and thus enhances the probability of uniform national administration of the laws"). 
statutes. Its effect is to preclude judges from second-guessing agency policy decisions by mischaracterizing those decisions as resolutions of questions of law."

The purpose of this Article is to explore the role of judicial convictions in the application of Chevron. Two data sets are analyzed. The first consists of all Supreme Court decisions between 1989 and 2005 that reviewed agency interpretations of law. ${ }^{10}$ This data set consists of eighty-four decisions, and we focus on sixty-nine in which the Court applied the Chevron framework. In the remaining fifteen decisions, the Court reviewed an agency decision but did not expressly apply Chevron. In many of these instances, a concurring or dissenting justice expressed the belief that the Court should have applied Chevron. Although the number of such decisions is too small to permit a formal analysis of the differences between Chevron and what we call "nonChevron" decisions, these cases offer hints as to the Court's willingness to apply Chevron and whether Chevron makes a difference within the Court.

The second data set includes decisions from the circuit courts of appeals, and it contains a substantially larger number of opinions, 253 . It consists of all published cases from 1990 through 2004 in which federal judges reviewed interpretations of law by the EPA and the NLRB. Of the 253 opinions, 183 involved the EPA, and 70 involved the NLRB. Federal circuit judges cast 758 votes in these cases. As in the Supreme Court opinions, the circuit courts typically resolved these cases by applying Chevron; in only 26 cases did they not apply it. The use of two data sets affords the opportunity to evaluate whether the Supreme Court and the circuit courts differ in their application of Chevron.

The simplest finding is that on both the Supreme Court and the courts of appeals, the application of the Chevron framework is greatly affected by the judges' own convictions. Whatever Chevron may say, the data reveal a strong relationship between the justices' ideological

\footnotetext{
9 Pierce, 1 Administrative Law $\$ 3.4$ at 148 (cited in note 7).

10 These cases were found by placing Chevron in the relevant databases. Hence we do not include any decisions that review agency interpretations of law without reference to Chevron, a category that might include decisions in which the Chevron framework was deemed inapplicable, and so deemed without discussion. Because Chevron is standardly cited in judicial review of agency interpretations of law, even in cases in which its framework does not apply, our method is unlikely to produce distortions even if the resulting data set is incomplete.

A note on research method: we began by asking research assistants to compile and code the cases in order to investigate our various hypotheses. After they produced their initial results, we recompiled and recoded the cases ourselves. Our own coding produced some differences in the numbers, but the central patterns were the same. See note 32 (discussing our decision to drop the data involving the Federal Communications Commission). The data can be obtained from the authors on request.
} 
predispositions and the probability that they will validate agency determinations. The most conservative justices are 30 percentage points more likely to vote to validate agency interpretations that are coded as conservative than to validate agency interpretations coded as liberal. By contrast, the more liberal justices are 27 percentage points more likely to vote to validate agency interpretations coded as liberal than to validate those coded as conservative. Moreover, the most conservative justices on the Supreme Court show a validation rate 19 percentage points lower when applying the Chevron framework to the interpretations of the Clinton administration than to those of the two Bush administrations - while the more liberal justices show a validation rate 6 percentage points higher under the Clinton administration than under the two Bush administrations. If judicial decisions under the Chevron framework are assessed in crudely political terms, the voting patterns of Supreme Court justices fit with the conventional groupings of the justices along political lines - a clear signal that the Chevron framework is not having the disciplining effect that it is supposed to have.

Consider also a remarkable fact: Justice Breyer, the Court's most vocal critic of a strong reading of Chevron, is the most deferential justice in practice, while Justice Scalia, the Court's most vocal Chevron enthusiast, $^{12}$ is the least deferential. Overall, the data show that the justices' validation rates are consistent with common perceptions of their political ideology. More liberal justices vote to validate at higher rates than more conservative justices. Moreover, it is unclear whether Chevron has any effect within the Court. Although the number of cases in which the Court did not apply Chevron is small and nonrandom, ideological disagreements in cases applying Chevron are as large as in cases not applying its two-step analysis. A casual comparison of Chevron and non-Chevron cases does not suggest that Chevron succeeds in dampening the influence of ideology in the Court's review of agency interpretations.

Within the courts of appeals, the patterns also reveal a strong influence of political convictions in judicial review of agency interpretations of law. When the agency decision is liberal, the average Democratic appointee to the appellate courts is about 14 percentage points

11 See Stephen Breyer, Judicial Review of Questions of Law and Policy, 38 Admin L Rev 363, 372-82 (1986) (characterizing the strong reading of Chevron as "seriously overbroad, counterproductive and sometimes senseless"); see also Stephen Breyer, Active Liberty: Interpreting Our Democratic Constitution 106-08, 130 (Knopf 2005) ("Deference to a reasonable agency interpretation of an ambiguous statutory provision often makes sense, but not always.").

12 See generally Antonin Scalia, Judicial Deference to Administrative Interpretations of Law, 1989 Duke L J 511 (defending the Chevron rule on the grounds that it gives effect to congressional intent). 
more likely to vote to validate the agency than the average Republican appointee. But when the agency decision is conservative, this pattern flips, and the average Democratic appointee is 19 percentage points less likely to vote to validate the agency decision than the average Republican appointee. This sharp reversal in validation rates indicates that, despite Chevron, industry groups are more likely to find a sympathetic reaction from Republican appointees than from Democratic appointees. Similarly, public interest groups do better with Democratic appointees, even under the Chevron framework. Overall, Democratic appointees are 17 percentage points more likely to vote in a stereotypically liberal fashion in Chevron cases than are Republican appointees.

These differences become even more stark when the composition of the appellate panels is considered. Perhaps most disturbingly, a Democratic appointee, sitting with two Democratic appointees, is 31.5 percentage points more likely to vote to uphold a liberal decision than a conservative one - and a Republican appointee, sitting with two Republican appointees, is over 40 percentage points more likely to vote to uphold a conservative decision than a liberal one. We do not place too much emphasis on the precise magnitudes of these differences, because the number of observations in the finer decompositions of the data is small. However, the role of political judgments in judicial review of agency interpretations of law, at both levels of appellate review, is unmistakable.

What are the implications of these findings? A full discussion would be beyond the scope of the present Article; our emphasis is on the data, not on what lessons to draw from it. But it is reasonable to suggest that the meaning of federal statutory law should not be based on whether a litigant has drawn a panel of judges appointed by a president from a particular party-or on whether the Supreme Court is dominated by judges of any particular ideological stripe. If this suggestion is accepted, a strong endorsement of the agency's law-interpreting power is the best way to achieve that goal. Whether or not that judgment is ultimately accepted, it is clear that as the law now stands, the application of the Chevron framework, and hence the meaning of federal regulatory law, shows a significant effect from the political convictions of federal judges.

\section{CHEVRON AND THE SUPREME COURT}

\section{A. Simple Predictions about the Influence of Chevron}

If the goal is to predict how Chevron might operate in practice, it is sensible to begin with some hypotheses. Of these, the first and simplest is that Chevron would tend to eliminate systematic differences 
among judges along political lines. On this view, the consequence of the two-step analysis should be to produce relatively uniform validation rates that do not correlate with the ideology of particular judges. We might call this the doctrinal hypothesis, based as it is on the view that existing doctrine, as reflected in Chevron, has successfully eliminated ideological differences within the judiciary.

A second hypothesis is that whatever Chevron says, political convictions actually continue to drive judicial review of agency interpretations of law. On this view, judges' political preferences influence and perhaps even determine how they decide cases. In the context of reviewing agency interpretations, this hypothesis suggests that judges are more likely to validate when the agency's conclusion conforms with their policy judgments, regardless of whether the statutory text is clear or ambiguous. Call this the realist hypothesis.

A third hypothesis emphasizes that the prevailing approach to statutory interpretation should influence application of the two-step analysis. In recent decades, a prominent approach has relied on the "plain meaning" as reflected in the statutory text. ${ }^{13}$ As Justice Scalia signaled long ago, those who believe that statutes have clear meanings will be more likely to invalidate agency action at Chevron Step One. ${ }^{14}$ Adherents to this approach should be less likely to validate the agency's interpretation. By contrast, Justice Breyer rejects "plain meaning" approaches, ${ }^{15}$ and he and others who eschew "plain meaning" might well be more likely to find textual ambiguity where Justice Scalia finds clarity. Those who do not find a "plain meaning" should be more likely to reach Chevron Step Two and ultimately to uphold reasonable agency interpretations of law. ${ }^{16}$

Of course there is no logical or necessary connection between adoption of "plain meaning" approaches and being "liberal" or "conservative." But as an empirical matter, the more conservative justices (Justices Antonin Scalia and Clarence Thomas) have embraced "plain

\footnotetext{
13 See, for example, Antonin Scalia, A Matter of Interpretation: Federal Courts and the Law 18-25 (Princeton 1997).

14 See Scalia, 1989 Duke L J at 521 (cited in note 12) ("One who finds more often (as I do) that the meaning of a statute is apparent from its text and from its relationship with other laws, thereby finds less often that the triggering requirement for Chevron deference exists.").

15 See Breyer, Active Liberty at 85-101 (cited in note 11) (arguing that "overemphasis on text can lead courts astray, divorcing law from life," and advocating "a purposive approach" to statutory interpretation).

16 It is possible, of course, that those who reject "plain meaning" will turn out to take a stronger, rather than weaker, stand against agency interpretations of law because they will emphasize legislative history and statutory purpose, both of which could, in principle, overcome agency interpretations under Chevron Step One. To describe a testable hypothesis, however, we are speculating that textualist judges will be more likely to invalidate agency decisions under that step.
} 
meaning" approaches and the more liberal justices have not. We might therefore hypothesize that the more textualist members of the Court, who also are more conservative, will be more willing to invalidate agency action on textual grounds under Step One. The less textualist members of the Court, who are more likely to find ambiguity, will be more inclined to affirm the agency action on reasonableness grounds. Call this the formalist hypothesis.

It is worth noting that the realist hypothesis on the one hand and the doctrinal and formalist hypotheses on the other have much in common with the two canonical models of judicial behavior in political science: the "attitudinal model" and the "legal model." The political science models seek to explain judicial behavior generally rather than in the specific context of review of agency action. In the "attitudinal model," a judge seeks to match a case's outcome to her own policy preferences, and she is largely able to do so. ${ }^{17}$ In the "legal model," by contrast, judges render decisions without reference to their own policy preferences, relying instead on the facts of the case, stare decisis, and relevant statutory provisions. ${ }^{18}$ A central difference between the "legal model" of political science and the doctrinal and formalist hypotheses we describe is that the latter identify Chevron and "plain meaning" as the operative mechanisms, rather than relying, as the "legal model" does, on generic notions of law.

A natural test of the doctrinal, realist, and formalist hypotheses would be to correlate the validation rates of judges in Chevron cases with the political leanings or interpretive approach of the judges. ${ }^{19}$ The immediate difficulty with this test is that judges who favor "plain meaning" are also politically conservative. Thus, the observation that "plain meaning" judges validate at lower rates would be equivalent to the observation that politically conservative judges validate at lower rates. Would the lower validation rates of these judges be attributable to their predilections or their approach?

To answer this question, and to test the competing hypotheses, we examine variations in the political or ideological content of the agency decisions. According to the doctrinal hypothesis, the probability that a judge votes to validate the agency should bear little relationship to the

17 The literature on the attitudinal model is large. For an example, see Saul Brenner and Harold J. Spaeth, Stare Indecisis: The Alteration of Precedent on the Supreme Court, 1946-1992 59-71 (Cambridge 1995).

18 See, for example, id at 72-88 (discussing and testing the legal model in stare decisis cases).

19 There is a fourth hypothesis, which we might call the bureaucratic hypothesis, to the effect that some justices would be more inclined to uphold agency decisions than others, whatever the ideological content of those decisions. We shall say a few words about this hypothesis below. We bracket it here to avoid undue complexity. 
ideological content of the agency decision. The same is true of the formalist hypothesis. The essential test of "plain meaning" - whether a statute's meaning is clear or ambiguous-should be independent of the ideological content of the agency interpretation.

The realist hypothesis offers a different prediction. In this view, judges invalidate when the agency decision conflicts with their political inclinations and validate when it conforms to those inclinations. Specifically, the realist hypothesis predicts, as the formalist alternative does not, that validation rates should correlate positively with the political content of agency decisions.

To test these predictions, we employ two proxies for the ideological content of the agency decisions-proxies that also seem to us of independent interest. The first proxy is simply whether the case was decided during a Democratic or Republican administration. For purposes of evaluating the ideological content of a judicial decision, it surely matters, as a general rule, whether the court is reviewing a decision under President Clinton or instead President George W. Bush. A natural objection to this measure is that litigation challenging agency decisions often consumes years. If the litigation spans two administrations, this proxy may incorrectly attribute an agency position to President Bush that was actually adopted under President Clinton. But this objection should not be overstated. For purposes of assessing the various hypotheses, it is important to identify the administration that is actually defending the regulation that is being challenged. Moreover, the concern about this measure is mitigated by the ability of a new administration to change the agency position and to settle litigation any time before the court renders its decision. ${ }^{20}$ Note also that we calculated a two year "lag" on presidential years, to take account of the possibility that presidents would be defending regulations of their predecessors. Under this variation, we obtained our same basic results.

The second measure codes an agency decision as "liberal," simply and crudely, by reference to the identity of the party challenging it. If an industry group or corporation challenges an agency decision, we code the decision as "liberal," not in the abstract, but for the purpose of assessing the legal issue involved in the case. We use this coding technique on the theory that if an industry is challenging a decision by the EPA, or if a company is challenging a decision by the NLRB, the agency's decision is likely to be perceived as liberal in the context of judicial review. If a public interest group or labor union challenges an

20 Another caveat is that the relatively short time period studied, 1989-2005, encompasses only one Democratic administration, the Clinton administration. However, for clarity we generally refer to the presidencies as Democratic or Republican.

21 Data available from the authors. 
agency decision, we code the decision as conservative, at least for that purpose. The advantage of this method of coding decisions is its mechanical and objective character. The disadvantage is its crudeness. In a small number of instances, we deviated from the coding rule when it produced an obvious error.

\section{B. Supreme Court Review in Chevron Cases}

1. Basic data.

Table 1 presents numbers that provide an initial assessment of the three hypotheses for Supreme Court justices. It reports validation rates in Chevron cases by justice, and it demonstrates that Chevron does not come close to equalizing the validation rates of the justices. Hence, the doctrinal hypothesis is inconsistent with the data. As both the formalist and realist accounts predict, the identity of the justice correlates with the likelihood of validation of the agency decision.

Column (1) shows that the overall validation rates vary by as many as 30 percentage points across the justices. Of the nine justices, Justices Breyer and Souter have the highest validation rates, at 81.8 percent and 77 percent, respectively. In contrast, Justices Thomas and Scalia, at 52.2 percent and 53.6 percent, respectively, have the lowest validation rates in Chevron cases. Although the sample sizes are relatively small, the difference in validation rates between Justices Scalia and Breyer is statistically significant, as is the difference between Justices Scalia and Souter. Similarly, Justice Thomas's validation rate is statistically different from those of Justices Breyer and Souter.

Note, however, that many of the differences are insignificant at the statistical level. For example, the apparently large gap in validation rates between Justice Rehnquist on the one hand and Justices Scalia and Thomas on the other-more than 10 percentage points-is not statistically significant. Taken as a whole, the evidence in column (1), while repudiating the doctrinal hypothesis, is largely consistent with both the realist and formalist hypotheses; conservative and "plain meaning" justices tend to validate the agency decision less often than justices who are liberal or do not subscribe to the "plain meaning" approach.

\footnotetext{
22 For example, some public interest groups that challenged agency decisions, such as Focus on the Family, were clearly not liberal, and cases had to be coded accordingly.
} 
TABLE 1

Validation Rates of Individual Supreme Court Justices in Chevron Cases: Total and by Ideological Content of Agency Decision (Means, Standard Errors in Parentheses, and Number of Observations in Brackets)

\begin{tabular}{|c|c|c|c|c|c|c|c|}
\hline \multirow[b]{2}{*}{ Justice } & \multirow[b]{2}{*}{$\begin{array}{c}\text { Total } \\
\text { (1) }\end{array}$} & \multicolumn{3}{|c|}{$\begin{array}{l}\text { Ideological Content } \\
\text { of Agency Decision }\end{array}$} & \multicolumn{3}{|c|}{ Party of Current President } \\
\hline & & $\begin{array}{l}\text { Liberal } \\
\text { (2) }\end{array}$ & $\begin{array}{c}\text { Not } \\
\text { Liberal } \\
\text { (3) }\end{array}$ & $\begin{array}{c}\text { Difference } \\
\text { of } \\
(2)-(3):\end{array}$ & $\begin{array}{c}\text { Democrat } \\
\text { (4) }\end{array}$ & $\begin{array}{l}\text { Republican } \\
\text { (5) }\end{array}$ & $\begin{array}{c}\text { Difference } \\
\text { of } \\
(4)-(5):\end{array}$ \\
\hline Stevens & $\begin{array}{c}.710 \\
(.055) \\
{[69]}\end{array}$ & $\begin{array}{c}.860 \\
(.053) \\
{[43]}\end{array}$ & $\begin{array}{c}.462 \\
(.100) \\
{[26]}\end{array}$ & $\begin{array}{l}.399 * * \\
\mathbf{( . 1 0 3 )}\end{array}$ & $\begin{array}{c}.806 \\
(.072) \\
{[31]}\end{array}$ & $\begin{array}{c}.632 \\
(.079) \\
{[38]}\end{array}$ & $\begin{array}{c}.175 \\
(.109)\end{array}$ \\
\hline Souter & $\begin{array}{c}.770 \\
(.054) \\
{[61]}\end{array}$ & $\begin{array}{c}.821 \\
(.062) \\
{[39]}\end{array}$ & $\begin{array}{c}.682 \\
(.102) \\
{[22]}\end{array}$ & $\begin{array}{l}.139 \\
(.113)\end{array}$ & $\begin{array}{c}.774 \\
(.076) \\
{[31]}\end{array}$ & $\begin{array}{c}.767 \\
(.079) \\
{[30]}\end{array}$ & $\begin{array}{c}.008 \\
(.110)\end{array}$ \\
\hline Breyer & $\begin{array}{c}.818 \\
(.059) \\
{[44]}\end{array}$ & $\begin{array}{c}.900 \\
(.056) \\
{[30]}\end{array}$ & $\begin{array}{c}.643 \\
(.133) \\
{[14]}\end{array}$ & $\begin{array}{l}.257 * * \\
(.129)\end{array}$ & $\begin{array}{c}.833 \\
(.078) \\
{[24]}\end{array}$ & $\begin{array}{c}.800 \\
(.092) \\
{[20]}\end{array}$ & $\begin{array}{l}.033 \\
\mathbf{( . 1 1 9 )}\end{array}$ \\
\hline Ginsburg & $\begin{array}{c}.740 \\
(.063) \\
{[50]}\end{array}$ & $\begin{array}{c}0.818 \\
(.068) \\
{[33]}\end{array}$ & $\begin{array}{c}.588 \\
(.123) \\
{[17]}\end{array}$ & $\begin{array}{l}.230 * \\
(.129)\end{array}$ & $\begin{array}{c}.724 \\
(.084) \\
{[29]}\end{array}$ & $\begin{array}{c}.762 \\
(.095) \\
{[21]}\end{array}$ & $\begin{array}{l}-.038 \\
(.128)\end{array}$ \\
\hline O’Connor & $\begin{array}{c}.677 \\
(.058) \\
{[65]}\end{array}$ & $\begin{array}{c}.625 \\
(.078) \\
{[40]}\end{array}$ & $\begin{array}{c}.760 \\
(.087) \\
{[25]}\end{array}$ & $\begin{array}{l}-.135 \\
(.120)\end{array}$ & $\begin{array}{c}.655 \\
(.090) \\
{[29]}\end{array}$ & $\begin{array}{c}.694 \\
(.078) \\
{[36]}\end{array}$ & $\begin{array}{l}-.039 \\
(.118)\end{array}$ \\
\hline Kennedy & $\begin{array}{c}.672 \\
(.058) \\
{[67]}\end{array}$ & $\begin{array}{c}.667 \\
(.074) \\
{[42]}\end{array}$ & $\begin{array}{c}.680 \\
(.095) \\
{[25]}\end{array}$ & $\begin{array}{l}-.013 \\
(.120)\end{array}$ & $\begin{array}{c}.774 \\
(.076) \\
{[31]}\end{array}$ & $\begin{array}{c}.583 \\
(.083) \\
{[36]}\end{array}$ & $\begin{array}{l}.191^{*} \\
(.114)\end{array}$ \\
\hline Rehnquist & $\begin{array}{c}.638 \\
(.058) \\
{[69]}\end{array}$ & $\begin{array}{c}.558 \\
(.077) \\
{[43]}\end{array}$ & $\begin{array}{c}.769 \\
(.084) \\
{[26]}\end{array}$ & $\begin{array}{l}-.211 * \\
(.118)\end{array}$ & $\begin{array}{c}.516 \\
(.091) \\
{[31]}\end{array}$ & $\begin{array}{c}.737 \\
(.072) \\
{[38]}\end{array}$ & $\begin{array}{l}-.221 * \\
(.115)\end{array}$ \\
\hline Scalia & $\begin{array}{c}.522 \\
(.061) \\
{[69]}\end{array}$ & $\begin{array}{c}.419 \\
(.076) \\
{[43]}\end{array}$ & $\begin{array}{c}.692 \\
(.092) \\
{[26]}\end{array}$ & $\begin{array}{l}-.273 * * \\
(.121)\end{array}$ & $\begin{array}{c}.419 \\
(.090) \\
{[31]}\end{array}$ & $\begin{array}{c}.605 \\
(.080) \\
{[38]}\end{array}$ & $\begin{array}{l}-.186 \\
(.121)\end{array}$ \\
\hline Thomas & $\begin{array}{c}.536 \\
(.067) \\
{[56]}\end{array}$ & $\begin{array}{c}.378 \\
(.081) \\
{[37]}\end{array}$ & $\begin{array}{c}.842 \\
(.086) \\
{[19]}\end{array}$ & $\begin{array}{l}-.464 * * \\
(.129)\end{array}$ & $\begin{array}{c}.484 \\
(.091) \\
{[31]}\end{array}$ & $\begin{array}{c}.600 \\
(.100) \\
{[25]}\end{array}$ & $\begin{array}{c}-.116 \\
(.143)\end{array}$ \\
\hline
\end{tabular}

Note: * denotes difference significant at 10 percent level, and ** denotes difference significant at 5 percent level. Differences may not match exactly due to rounding.

Although the doctrinal hypothesis cannot stand, we can easily see that the ordering of the justices by validation rates largely conforms with the standard alignment of justices on the ideological spectrum. The justices generally thought to be liberal-Justices Stevens, Souter, Breyer, and Ginsburg - have validation rates in excess of 70 percent. The justices generally thought to be conservative-Justices Scalia and 
Thomas - have validation rates under 55 percent. The validation rates of justices generally thought to be swing voters-Justices O'Connor and Kennedy - fall in the middle, at about 67 percent. The dominant pattern of column (1) is that justices standardly characterized as liberal have the highest validation rates, while the justices standardly characterized as conservative have the lowest validation rates. The justice who is most difficult to classify is Chief Justice Rehnquist. The level of his overall validation rate, at about 64 percent, suggests that he should be grouped with Justices O'Connor and Kennedy. However, as the subsequent columns of Table 1 show, Rehnquist's validation rate correlates strongly with the political content of agency action, and this pattern makes his validation rate more akin to that of Justices Scalia and Thomas rather than that of O'Connor and Kennedy. At the same time, it is also striking that the highest validation rate comes from the Court's strongest critic of Chevron (Justice Breyer), ${ }^{23}$ whereas the lowest validation rate comes from the Court's strongest Chevron enthusiast (Justice Scalia). ${ }^{24}$ In view of this finding alone, it would be reasonable to speculate that a judge's formal position on the deference principle matters much less than one might think.

Columns (2) and (3) of Table 1 report the rates at which each justice validates a liberal agency decision (or, equivalently, rejects a challenge to an agency decision by an industry group). Columns (4) and (5) present similar estimates when the rates are stratified by the party of the current president. The Table also reports the differences between these measures for each justice. Notably, the validation rates of some justices, such as Justice O'Connor, are nearly constant across administrations, and others, such as Justice Kennedy, are unaffected by whether the agency's decision was liberal. In contrast, the validation rates of other justices fluctuate dramatically in accordance with politics. The validation rates of Justices Stevens, Breyer, and Ginsburg move by more than 20 percentage points when the nature of the agency decision changes. Similarly, the rates of Justices Rehnquist, Scalia, and Thomas swing by more than 20 percentage points with a switch in the political content of the agency decision.

In Table 1, the validation rates of the conservative justices appear more sensitive to the presidential administration. However, as previously mentioned, our method of identifying administrations - the party of the occupant of the White House at the time that the Court issues its decision - is somewhat arbitrary. The fact that litigation takes a year or

\footnotetext{
23 See Breyer, Active Liberty at 106-08, 130 (cited in note 11); Breyer, 38 Admin L Rev at 372-82 (cited in note 11 ).

24 See generally Scalia, 1989 Duke L J 511 (cited in note 12).
} 
more to reach the Court suggests an alternative specification of lagging the dates of a change in administration by a year or two. Although we do not report these specifications here to conserve space, these alternative specifications show that the more liberal justices appear as sensitive to the party of the current administration as the more conservative justices do. Although the magnitudes exhibit some sensitivity and the small number of observations make statistical significance difficult to attain, the role of politics is hard to miss.

The direction of these movements is largely consistent with conventional wisdom about each justice's ideological orientation. Justices on the conservative wing of the court-Rehnquist, Scalia, and Thomas - validate at higher rates during Republican administrations than Democratic administrations. Justices on the liberal wing of the courtsuch as Stevens and Ginsburg - validate at much higher rates when the agency decision is liberal than when it is not. The validation rates of Justices Kennedy, Souter, and O'Connor, who typically are cast as the moderate or "swing" justices, are less consistently correlated with the ideological content of the agency decision.

\section{Evaluating the hypotheses.}

As is readily apparent from these figures, the formalist explanation does not square well with these results, and the realist explanation seems to fare much better. When the agency action is not liberal, Chief Justice Rehnquist and Justices Scalia and Thomas show significant increases in validation rates. When the agency action is liberal, Justices Souter, Ginsburg, Breyer, and Stevens show large increases in validation rates. Justice Kennedy's validation rates show some sensitivity to the party of the current president, but not to the ideological content of the agency decision. Justice O'Connor's validation rates display the opposite pattern-some sensitivity to the political content of the agency decision but not to the administration.

It is usual to sort the justices into three groups: the conservatives (Rehnquist, Scalia, and Thomas, or RST); the swing votes (O'Connor and Kennedy, or OK); and the liberals (Souter, Stevens, Ginsburg, and Breyer, or SSGB). To obtain a better test of the competing hypothesis, we aggregate the justices into these three widely acknowledged groups. The data themselves provide some justification for these groupings. The RST group features a validation rate of about 57 percent, the OK group one of 67 percent, and the SSBG group one of 75 percent. The difference in rates between the SSBG group and the RST group is statistically significant at the 5 percent level. Tables 2 and 3 report these fig- 
ures as well as validation rates by the ideological nature of the agency decision and by presidential administration, respectively. ${ }^{25}$

TABLE 2

Validation Rates of Groups of Supreme Court Justices in Chevron

Cases: Total and by Ideological Content of Agency Decision (Means, Standard Errors in Parentheses, and Number of Observations in Brackets)

\begin{tabular}{|c|c|c|c|c|}
\hline \multirow[b]{2}{*}{ Justice } & \multirow[b]{2}{*}{$\begin{array}{c}\text { Total } \\
(1)\end{array}$} & \multicolumn{3}{|c|}{ Ideological Content of Agency Decision } \\
\hline & & $\begin{array}{c}\text { Liberal } \\
\text { (2) }\end{array}$ & $\begin{array}{l}\text { Not Liberal } \\
\text { (3) }\end{array}$ & $\begin{array}{l}\text { Difference } \\
\text { of }(2)-(3) \text { : }\end{array}$ \\
\hline Stevens, Souter, Breyer \& Ginsburg & $\begin{array}{c}.754 \\
(.029) \\
{[224]}\end{array}$ & $\begin{array}{c}.848 \\
(.030) \\
{[145]}\end{array}$ & $\begin{array}{c}.582 \\
(.056) \\
{[79]}\end{array}$ & $\begin{array}{l}.266 * * \\
(.058)\end{array}$ \\
\hline O’Connor \& Kennedy & $\begin{array}{c}.674 \\
(.041) \\
{[132]}\end{array}$ & $\begin{array}{c}.646 \\
(.053) \\
{[82]}\end{array}$ & $\begin{array}{c}.720 \\
(.064) \\
{[50]}\end{array}$ & $\begin{array}{l}-.074 \\
(.084)\end{array}$ \\
\hline Rehnquist, Scalia \& Thomas & $\begin{array}{c}.567 \\
(.036) \\
{[194]}\end{array}$ & $\begin{array}{l}.455 \\
(.045) \\
{[123]}\end{array}$ & $\begin{array}{c}.761 \\
(.051) \\
{[71]}\end{array}$ & $\begin{array}{c}-.305 * * \\
(.071)\end{array}$ \\
\hline Difference of SSBG-OK & $\begin{array}{l}.080 * \\
(.049)\end{array}$ & $\begin{array}{l}.202 * * \\
(.056)\end{array}$ & $\begin{array}{c}-.138 \\
(.087)\end{array}$ & -- \\
\hline Difference of SSBG-RST & $\begin{array}{l}.187^{* * *} \\
(.045)\end{array}$ & $\begin{array}{l}.393 * * \\
(.053)\end{array}$ & $\begin{array}{c}-.178^{* * *} \\
(.076)\end{array}$ & -- \\
\hline Difference of OK-RST & $\begin{array}{l}.107 * \\
(.055)\end{array}$ & $\begin{array}{l}.191 * * \\
(.070)\end{array}$ & $\begin{array}{c}-.041 \\
(.081)\end{array}$ & -- \\
\hline
\end{tabular}

Note: * denotes difference significant at 10 percent level, and ** denotes difference significant at 5 percent level. Differences may not match exactly due to rounding.

Tables 2 and 3 show more concisely what was already apparent in Table 1: the validation rates of the SSBG and RST groups correlate with the ideological content of agency decisions. Table 2 shows that the validation rates of SSBG move by more than 25 percentage points, a statistically significant difference, and those of the RST group move by more than 30 percentage points. Table 3 reports that when the party of the current president is used as the measure of the political content of the agency interpretation, these differences are about 6 percentage points for the SSBG group and 18 percentage points for the RST group. Both of these movements are in the expected direction. 
TABLE 3

Validation Rates of Groups of Supreme Court Justices in Chevron Cases: Total and by Party of Current President (Means, Standard Errors in Parentheses, and Number of Observations in Brackets)

\begin{tabular}{|c|c|c|c|c|}
\hline \multirow[b]{2}{*}{ Justice } & \multirow[b]{2}{*}{$\begin{array}{c}\text { Total } \\
\text { (1) }\end{array}$} & \multicolumn{3}{|c|}{ Party of Current President } \\
\hline & & $\begin{array}{c}\text { Democratic } \\
\text { (2) }\end{array}$ & $\begin{array}{c}\text { Republican } \\
\text { (3) }\end{array}$ & $\begin{array}{l}\text { Difference } \\
\text { of }(2)-(3) \text { : }\end{array}$ \\
\hline Stevens, Souter, Breyer \& Ginsburg & $\begin{array}{c}.754 \\
(.029) \\
{[224]}\end{array}$ & $\begin{array}{c}.783 \\
(.038) \\
{[115]}\end{array}$ & $\begin{array}{c}.725 \\
(.043) \\
{[109]}\end{array}$ & $\begin{array}{c}.058 \\
\mathbf{( . 0 5 8 )}\end{array}$ \\
\hline O’Connor \& Kennedy & $\begin{array}{c}.674 \\
(.041) \\
{[132]}\end{array}$ & $\begin{array}{c}.717 \\
(.059) \\
{[60]}\end{array}$ & $\begin{array}{c}.639 \\
(.057) \\
{[72]}\end{array}$ & $\begin{array}{c}.078 \\
(.082)\end{array}$ \\
\hline Rehnquist, Scalia \& Thomas & $\begin{array}{l}.567 \\
(.036) \\
{[194]}\end{array}$ & $\begin{array}{c}.473 \\
(.052) \\
{[93]}\end{array}$ & $\begin{array}{l}.653 \\
(.048) \\
{[101]}\end{array}$ & $\begin{array}{c}-.180 * * \\
(.070)\end{array}$ \\
\hline Difference of SSBG-OK & $\begin{array}{c}.080 \\
(.049)\end{array}$ & $\begin{array}{c}.066 \\
(.068)\end{array}$ & $\begin{array}{c}.086 \\
(.070)\end{array}$ & -- \\
\hline Difference of SSBG-RST & $\begin{array}{l}.187 * * \\
(.049)\end{array}$ & $\begin{array}{l}.309 * * \\
(.064)\end{array}$ & $\begin{array}{c}.071 \\
(.064)\end{array}$ & -- \\
\hline Difference of OK-RST & $\begin{array}{l}.107 * \\
(.055)\end{array}$ & $\begin{array}{l}.243 * * \\
(.080)\end{array}$ & $\begin{array}{l}-.015 \\
(.074)\end{array}$ & -- \\
\hline
\end{tabular}

Note: * denotes difference significant at 10 percent level, and ** denotes difference significant at 5 percent level. Differences may not match exactly due to rounding.

These movements also show that it is not easy to conclude that one wing of the Court is more responsive to the politics of a case than the other wing. In Table 2, when the cases are stratified according to whether the agency decision was liberal, the fluctuations in the validation rates of the RST and SSBG groups are similar in magnitudes; but in Table 3, when the cases are grouped by party of the current president, the RST group exhibits a larger movement. Moreover, the magnitudes of these differences -30.5 versus 26.6 percentage points, and 18 versus 5.8 percentage points - are not so large as to make these differences statistically different from each other.

At the same time, Tables 2 and 3 consistently show that liberal judges validate at higher rates when the agency decision is liberal rather than conservative, and the reverse is true for conservative justices. By comparison, in both Table 2 and 3, the validation rate of the OK group shows only modest movements. For each measure, the difference in the validation rates of the $\mathrm{OK}$ group is less than 10 percentage points, and neither is statistically significant. 


\section{Qualified realism.}

The figures in these initial tables provide some support for the realist explanation, but they are not an unqualified confirmation of it. A strong version of the realist view would predict that conservative justices should exhibit high validation rates under Bush and low rates under Clinton-and the converse should be true for liberal justices. Committed realists might also be inclined to predict symmetry between conservative and liberal justices. When conservative justices review agency decisions that match their policy preferences, they should validate at rates just as high as the validation rates of liberal justices when the latter encounter agency decisions that match their policy preferences. Similarly, the validation rates of conservative justices should be just as low as those of liberal justices when they face agency interpretations contrary to their political leanings. In effect, the validation rates of conservative and liberal justices should simply switch levels depending on whether the agency interpretation matches their policy preferences.

The tables do not consistently establish this simple pattern, but Table 2 provides the strongest support for it. The likelihood that the SSBG group validates an agency decision is more than 25 percentage points higher when that decision is liberal, and the opposite is true for the RST group. The validation rate of the OK group shows little movement depending on the ideological content of the agency decision. To put it differently, the validation rates of the three groups of justices in Table 2 rank according to whether the political content of the agency decision is closest to the justices' ideological preferences.

The estimates in Table 3, however, do not lend themselves as easily to a realist interpretation. Those figures show that the validation rates of the SSBG group are less responsive to the current administration and are everywhere higher than the validation rate of the RST group. As described above, the estimates by administration are sensitive to how we define presidential administrations, but if taken at face value, the estimates in Table 3 are not wholly consistent with the simplest version of realism. Thus, the strong version of the realist hypothesis - that liberal and conservative justices will have validation rates that are mirror images of each other-does not find support in Table 3.

The absence of a symmetrical pattern of seesawing validation rates in Table 3 suggests that the realist model requires enrichment, or the formalist model retains some relevance, or both. The first possibility is that the formalist account might have some continuing vitality. Although the validation rates of the RST group fluctuate with the administration - in contradiction of the simple version of the formalist 
model-their validation rates in Table 3 never exceed those of the SSBG group. This finding seems to support the formalist account, because it is consistent with the hypothesis that the followers of the "plain meaning" approach are more likely to conclude a text is unambiguous and to forgo validation of the agency. ${ }^{26}$

The second possibility is that a more fully articulated realist model might also be consistent with these results. Liberal judges are generally thought to be more deferential to administrative expertise and regulatory judgment - a theme that runs throughout Justice Breyer's writing. ${ }^{27}$ This view reflects a faith in the expertise and political accountability of agencies, and this faith is likely to motivate judges to validate agencies, even when they render decisions at odds with a justice's own policy preference. Call this the bureaucratic hypothesis, one that would predict a higher rate of validation by the liberal justices simply because they are more receptive to the exercise of discretion by regulatory institutions, regardless of their ideological valence.

The data do not permit us to distinguish clearly the role of "plain meaning" approaches, variations in trust in bureaucracies, and pure political preferences. Indeed, it is difficult to envision data that would permit precise measurement of these influences. However, the data offer some support for each explanation. First and perhaps most important, the realist model receives clear support from the finding that probabilities of validation on the opposing wings of the Court correlate with whether the agency decision is liberal. Second, the "plain meaning" methodology reduces the likelihood that its followers at any time will vote to validate. The prediction of this account is that subscription to the "plain meaning" approach will bias downward the validation rates of its followers. Consistent with this prediction, the RST group has an overall rate of validation lower than those of the other justices. ${ }^{28}$ Third, belief in bureaucratic competence should increase the

26 To explore further the importance of the "plain meaning" approach, we examined the decisions in which the Court under Chevron invalidated the agency interpretation and asked whether particular groups of justices were more likely to invalidate under Step One or Step Two. We found no substantial differences between the groups of justices in their likelihood of employing Step One or Step Two to invalidate. More than 90 percent of invalidations under Chevron occurred under Step One.

27 See Stephen Breyer, Breaking the Vicious Circle: Toward Effective Risk Regulation 61-63 (Harvard 1993) (discussing the bureaucratic virtues of rationalization, expertise, insulation, and authority).

28 We recognize that Chief Justice Rehnquist did not subscribe to the "plain meaning" approach nearly as clearly as Justices Scalia and Thomas do. Indeed, Justice Rehnquist's overall deference rate -64 percent -is well above that of Justices Scalia and Thomas - 54 percent. However, when Justice Rehnquist's deference rate is compared to those of all eight other justices, we believe that it is reasonable for purposes of this analysis to group him with Justices Scalia and Thomas. 
likelihood that justices will vote to validate the agency at all times. Consistent with this prediction, the SSBG group has an overall rate of validation as least at high as those of the other justices.

\section{An objection.}

A possible objection to these findings is that they fail to control for other factors influencing the justices' conclusions. For example, one hypothesis could be that the willingness of justices to validate an agency may have changed with the passage of time since Chevron, perhaps because the justices have grown accustomed to exercising deference or to applying the Chevron steps. Similarly, an examination of aggregate validation rates does not control for the characteristics of the cases, such as which agency is involved, the quality of the lawyers' advocacy, the degree to which the particular challengers are sympathetic, the willingness of parties to appeal agency decisions, and other differences. If such differences vary systematically with the likelihood that the justices vote to validate, and especially if they correlate with the political content of the cases, the estimates may be biased. A failure to control for such differences could therefore lead to improper inferences about the role of politics in Chevron analysis.

To explore the robustness of the estimates to other potential influences on the likelihood that a justice validates, we conducted a regression analysis. Although the regressions did not permit us to account for selection effects, they allowed us to employ crude controls for some possibly confounding factors. Two sets of controls or additional explanatory variables were included in the regressions. First, indicator variables for each year, or so-called year fixed effects, controlled for any trends over time in the probability that a justice votes to validate. Second, indicator variables for each case held constant any variation across cases in the likelihood that a justice validates. The resulting estimates were remarkably similar to the summary statistics. When the agency decision is liberal or the president is a Democrat, the SSBG and RST groups have validation rates that are significantly higher and lower, respectively, than the OK group. But when the agency decision is not liberal or the president is a Republican, the validation rates of the three groups of justices are indistinguishable. As the regression analysis adds little to our analysis thus far, we do not report the regression results separately here.

The analysis here has been somewhat complex, and it will be useful to emphasize some of our principal findings by way of conclusion.

29 A more detailed description of the functional forms and specifications employed, as well as the regression estimates themselves, are available from the authors upon request. 
When the agency decision is liberal, the RST group validates at a lower rate, and the opposite is true for the SSBG group. The results support the realist hypothesis. The validation rate of the RST group appears sensitive to the political content of the agency decision and to the party of the current president. When stratified by presidential administration, the validation rate of the SSBG group is always higher than that of the RST group. This result poses a challenge for a strong version of the realist account. These results are readily apparent in sample means and are robust to regression specifications that explain more of the variation in the probability of validation.

\section{Liberal and Conservative Voting}

Our analysis has coded cases in terms of the ideological valence of the agency's decisions, which enables us to test the three hypotheses with which we began. But it is also possible to produce an aggregated data set, simply by coding judicial voting in liberal or conservative terms. By this measure, we counted a judicial vote as liberal if it favors upholding an agency interpretation against industry challenge or if it favors invalidating an agency interpretation against the challenge of a public interest group (or labor union). With this aggregate measure, we obtain additional support for the qualified realist hypothesis.

Table 4 presents the rates of liberal voting for the three groups of justices. Consistent with standard perceptions of the justices, the SSBG group casts liberal votes at higher rates, and the RST group at lower rates. The liberal voting rate of the OK group falls between them. The most striking finding is a 30 percentage point overall difference in liberal votes between the SSBG and RST groups. This difference is statistically significant-as is the 16 percentage point difference between SSBG and OK. Indeed, the differences between the SSBG group and the RST and OK groups are at least 15 percentage points and are statistically significant in both Democratic and Republican administrations. In addition to according with common perceptions of the justices, these results provide direct support for the realist hypothesis. 
TABLE 4

Liberal Voting Rates of Groups of Supreme Court Justices in Chevron Cases: Total and by Party of Current President (Means, Standard Errors in Parentheses, and Number of Observations in Brackets)

\begin{tabular}{|c|c|c|c|c|}
\hline \multirow[b]{2}{*}{ Justice } & \multirow[b]{2}{*}{$\begin{array}{c}\text { Total } \\
(1)\end{array}$} & \multicolumn{3}{|c|}{ Party of Current President } \\
\hline & & $\begin{array}{c}\text { Democratic } \\
\text { (2) }\end{array}$ & $\begin{array}{c}\text { Republican } \\
\text { (3) }\end{array}$ & $\begin{array}{l}\text { Difference } \\
\text { of }(2)-(3) \text { : }\end{array}$ \\
\hline Stevens, Souter, Breyer \& Ginsburg & $\begin{array}{c}.670 \\
(.031) \\
{[224]}\end{array}$ & $\begin{array}{c}.730 \\
(.042) \\
{[115]}\end{array}$ & $\begin{array}{c}.606 \\
(.047) \\
{[109]}\end{array}$ & $\begin{array}{l}.125 * * \\
\mathbf{( . 0 6 3 )}\end{array}$ \\
\hline O’Connor \& Kennedy & $\begin{array}{c}.508 \\
(.044) \\
{[132]}\end{array}$ & $\begin{array}{c}.567 \\
(.065) \\
{[60]}\end{array}$ & $\begin{array}{c}.458 \\
(.059) \\
{[72]}\end{array}$ & $\begin{array}{c}.108 \\
(.088)\end{array}$ \\
\hline Rehnquist, Scalia \& Thomas & $\begin{array}{c}.366 \\
(.035) \\
{[194]}\end{array}$ & $\begin{array}{c}.387 \\
(.051) \\
{[93]}\end{array}$ & $\begin{array}{c}.347 \\
(.048) \\
{[101]}\end{array}$ & $\begin{array}{c}.041 \\
(.070)\end{array}$ \\
\hline Difference of SSBG-OK & $\begin{array}{l}.162 * * \\
(.053)\end{array}$ & $\begin{array}{l}.164 * * \\
(.074)\end{array}$ & $\begin{array}{l}.147 * * \\
(.075)\end{array}$ & -- \\
\hline Difference of SSBG-RST & $\begin{array}{l}.304 * * \\
\mathbf{( . 0 4 7 )}\end{array}$ & $\begin{array}{l}. \mathbf{3 4 3} * * \\
(.065)\end{array}$ & $\begin{array}{l}.259 * * \\
(.067)\end{array}$ & -- \\
\hline Difference of OK-RST & $\begin{array}{l}.142 * * \\
(.055)\end{array}$ & $\begin{array}{l}.180 * * \\
(.082)\end{array}$ & $\begin{array}{l}.112 \\
(.075)\end{array}$ & -- \\
\hline
\end{tabular}

Note: * denotes difference significant at 10 percent level, and ** denotes difference significant at 5 percent level. Differences may not match exactly due to rounding.

At the same time, there are noteworthy differences across administrations. All three groups of justices show somewhat higher liberal voting rates in Democratic administrations. The increase in liberal votes in Democratic administrations is consistent with the view that Chevron actually has an effect. If Chevron succeeds in restraining the political preferences of the justices, liberals should have lower liberal voting rates when the president is Republican because Chevron should cause liberals to validate some conservative agency decisions. Similarly, it should cause conservatives to have higher liberal voting rates when the president is Democratic because it requires conservatives to validate some liberal agency decisions. For both liberal and conservative justices, liberal voting rates should be higher during Democratic presidencies and lower in Republican ones. Table 4 offers some qualified support for this prediction. For the SSBG and OK groups, the rate of liberal voting rises by more than 10 percentage points when a Democrat is president. In contrast, the increase for the RST group is only 4 percentage points. These results provide partial support for both the 
doctrinal and realist hypotheses, though the realist view seems to do somewhat better.

\section{Chevron and Non-Chevron Review in the Supreme Court}

The analysis thus far shows that even with the constraint of Chevron's two-step framework, politics continues to play a role in the judicial review of agency decisions. This influence of politics is, however, only a partial answer to the larger question of how Chevron affects judicial review of agency interpretations. An answer to this broader question requires an assessment of whether, in the absence of Chevron, politics would exert a stronger influence in judicial review. Nothing that we have said thus far precludes the possibility that Chevron has had some equalizing influence. ${ }^{30}$ In other words, the significance of the findings thus far is difficult to assess because they do not provide a baseline of what judicial review would occur in the absence of Chevron.

The ideal baseline for evaluating this broader significance is the counterfactual of judicial review without Chevron. We could imagine a thought experiment in which courts would divide review of agency decisions into two groups. In one group, the court would be required to apply Chevron, and in the other, it would be required not to do so. The difference in the validation rates between these two groups of cases would provide a measure of Chevron's impact on judicial review. Of course, we cannot conduct this ideal experiment. The analysis to follow is somewhat complex; the largest lesson is that we find no evidence that Chevron is influencing ideological voting on the Court.

The justices themselves decide whether and when to apply Chevron. In the jargon of statistics, the application of Chevron is not exogenous. Rather, its application is, to some degree, an interpretive choice of the Court itself. The doctrinal and the realist hypotheses disagree about the extent to which the justices have discretion to exercise this choice, and consequently, these accounts make different predictions about the frequency of Chevron application and the pattern of validation in non-Chevron cases. A simple realist account assumes that justices enjoy wide discretion in deciding whether to apply Chevron and that they employ Chevron deference strategically. The realist account predicts that justices will be more inclined to apply Chevron when they want to uphold agency action, and less inclined to apply Chevron when they want to invalidate agency action. In the realist account, the rate at which justices vote to apply Chevron should be higher when the agency action matches the justice's ideological pref-

30 For an early discussion, see Schuck and Elliott, 1990 Duke L J at 1057-59 (cited in note 6) (concluding that Chevron led to an increase in deference to agency decisions). 
erences and lower when it does not match. An unmitigated realist view also predicts that legal doctrines, such as Chevron deference, are objects for judicial manipulation rather than binding constraints on justices' efforts to implement their preferred policies. Therefore, a realist prediction is that validation rates should correlate with ideological preferences, irrespective of whether the Court applies Chevron. In cases not involving Chevron deference, judicial behavior should be essentially the same.

In contrast, a simple doctrinal account assumes that the doctrine imposes sharp limits on the justices' ability to refuse to apply Chevron and that there is nothing like unbounded freedom to apply Chevron as the justices see fit. In the doctrinal view, the rate of Chevron application should not vary much across individual justices and should not correlate with the ideological likings of the justices. Moreover, the doctrinalist perceives Chevron itself as a restraint on judicial policymaking. This view predicts that Chevron, as a doctrine of deference, should weaken the correlation between the politics of the agency decision and the justice's willingness to validate that decision. In this account, the justices should more readily vote according to their ideological preferences when the Court does not apply Chevron than when it does. Ideological voting should be less apparent in Chevron cases than non-Chevron cases.

Our data permit tests of these predictions. Again, the number of cases in which the Court reviewed an agency decision but did not apply Chevron is small-15 cases, representing 120 votes by justices in the sample. Our analysis is therefore speculative, but we can advance a few tentative conclusions. First, Table 5 reports the rates at which the three groups of justices voted to apply Chevron. There is little variation overall in the rate at which the three groups of justices voted to apply Chevron. All three groups voted to apply Chevron more than three-fourths of the time, and their rates differ by at most 6 percentage points. Moreover, the largest difference in their overall rates of voting to apply Chevron arises not in the two most ideologically distant groups - SSBG and RST - but between the liberals and the moderates-SSBG and OK. These estimates suggest that the discretion of the justices to apply Chevron is rather limited. ${ }^{31}$

\footnotetext{
31 See, for example, Barnhart v Walton, 535 US 212, 221-22 (2002); United States v Mead Corp, 533 US 218, 231-34 (2001) (holding that a limited class of agency interpretations do not merit Chevron deference).
} 
TABLE 5

Supreme Court Justices' Rates of Voting to Apply Chevron: By Groups of Justices and by Party of Current President (Means, Standard Errors in Parentheses, and Number of Observations in Brackets)

\begin{tabular}{|c|c|c|c|c|}
\hline \multirow[b]{2}{*}{ Justice } & \multirow[b]{2}{*}{$\begin{array}{c}\text { Total } \\
\text { (1) }\end{array}$} & \multicolumn{3}{|c|}{ Party of Current President } \\
\hline & & $\begin{array}{l}\text { Democratic } \\
\text { (2) }\end{array}$ & $\begin{array}{c}\text { Republican } \\
\text { (3) }\end{array}$ & $\begin{array}{l}\text { Difference } \\
\text { of }(2)-(3) \text { : }\end{array}$ \\
\hline Stevens, Souter, Breyer, \& Ginsburg & $\begin{array}{c}.813 \\
(.024) \\
{[273]}\end{array}$ & $\begin{array}{c}.831 \\
(.028) \\
{[177]}\end{array}$ & $\begin{array}{c}.781 \\
(.042) \\
{[96]}\end{array}$ & $\begin{array}{c}.049 \\
(.049)\end{array}$ \\
\hline O’Connor \& Kennedy & $\begin{array}{l}.759 \\
(.034) \\
{[162]}\end{array}$ & $\begin{array}{l}.750 \\
(.044) \\
{[100]}\end{array}$ & $\begin{array}{c}.774 \\
(.054) \\
{[62]}\end{array}$ & $\begin{array}{l}-.024 \\
(.070)\end{array}$ \\
\hline Rehnquist, Scalia, \& Thomas & $\begin{array}{c}.783 \\
(.027) \\
{[235]}\end{array}$ & $\begin{array}{c}.757 \\
(.035) \\
{[148]}\end{array}$ & $\begin{array}{c}.828 \\
(.041) \\
{[87]}\end{array}$ & $\begin{array}{l}-.071 \\
(.056)\end{array}$ \\
\hline Difference of SSBG-OK & $\begin{array}{c}.054 \\
(.040)\end{array}$ & $\begin{array}{c}.081 \\
(.050)\end{array}$ & $\begin{array}{c}.007 \\
(.068)\end{array}$ & -- \\
\hline Difference of SSBG-RST & $\begin{array}{c}.030 \\
(.036)\end{array}$ & $\begin{array}{c}.074 \\
(.045)\end{array}$ & $\begin{array}{c}-.046 \\
(.059)\end{array}$ & -- \\
\hline Difference of OK-RST & $\begin{array}{l}-.024 \\
(.043)\end{array}$ & $\begin{array}{l}-.007 \\
(.056)\end{array}$ & $\begin{array}{l}-.053 \\
(.066)\end{array}$ & -- \\
\hline
\end{tabular}

Note: * denotes difference significant at 10 percent level, and ** denotes difference significant at 5 percent level. Differences may not match exactly due to rounding.

The estimates in Table 5 therefore offer substantial support for the doctrinal view, but when the data are decomposed according to whether the agency decision was liberal, a modest ideological pattern emerges. When the agency decision is liberal, the rate at which the SSBG group applies the Chevron framework rises by 5 percentage points and that at which the RST group applies it falls by about 7 percentage points. The movement in the rate of the OK group is smaller-only 2 percentage points. Although none of these differences is statistically significant, the direction of the small fluctuations is consistent with the ideological preferences of the justices. The results in Table 5 suggest that the decision to apply Chevron is ideologically contested by the justices.

Table 6 assesses the more important prediction of the doctrinal and realist hypotheses by reporting comparisons of Chevron and nonChevron cases according to whether the agency decision was liberal. The table consists of three panels, one for each of the three groups of justices. It is readily apparent that the justices' validation rates in Chevron cases are, for the most part, not substantially different from those in 
non-Chevron cases. For the SSBG group, the validation rates in nonChevron cases are actually slightly higher than in Chevron cases, but the gap is small-at most 6.5 percentage points in cases when the agency decision was not liberal. In non-Chevron cases, the frequency of the SSBG group's voting to validate correlates with the political content of the agency decision about as closely as it does in Chevron cases. In particular, the magnitude of the fluctuation in the SSBG group's validation votes between liberal and nonliberal agency decisions is, at 26.6 and 22.8 percentage points, roughly the same in Chevron and non-Chevron cases.

Panel III shows an analogous pattern for the RST group. In Chevron cases, the RST group on average votes about 10 percentage points more often to validate than in non-Chevron cases, but given the small number of observations, this difference is not statistically significant. As Table 2 showed, the RST group validates nonliberal agency actions under Chevron at a rate more than 30 percentage points higher than that of liberal agency actions. Strikingly, Panel III of Table 6 displays a similar pattern among non-Chevron cases; there, the RST group votes to validate a liberal agency decision about 37 percentage points less often.

In contrast, the OK group's validation rate varies little with the political content of the agency decision, and as shown in Panel II of Table 6, this pattern holds true regardless of whether the Court applied Chevron. The most noteworthy difference in the OK group's votes is the overall gap between Chevron and non-Chevron cases in the rate of validation. The overall rate of validation by these justices is about 30 percentage points higher in Chevron than non-Chevron cases. The OK group therefore exhibits a very different pattern from either the SSBG or RST groups. For the OK group, the political content of the agency decision matters little in likelihood of validation, but whether the Court applies Chevron matters a great deal. For the SSBG and RST groups, the political content of the agency decision bears a strong relationship to the likelihood of validation, but the application of Chevron does not. 
TABLE 6

Validation Rates of Supreme Court Justices: By Groups of Justices, by Ideological Content of Agency Decision, and by Chevron Status (Means, Standard Errors in Parentheses, and Number of Observations in Brackets)

I. Justices Stevens, Souter, Breyer, and Ginsburg

\begin{tabular}{|c|c|c|c|}
\hline \multirow[b]{2}{*}{ Type of Analysis } & \multicolumn{3}{|c|}{ Ideological Content of Agency Decision } \\
\hline & $\begin{array}{l}\text { Liberal } \\
\text { (1) }\end{array}$ & $\begin{array}{c}\text { Not Liberal } \\
\text { (2) }\end{array}$ & $\begin{array}{l}\text { Difference of } \\
\text { (1)-(2): }\end{array}$ \\
\hline $\begin{array}{l}\text { (A) Court Applied } \\
\text { Chevron }\end{array}$ & $\begin{array}{c}.848 \\
(.030) \\
{[145]}\end{array}$ & $\begin{array}{c}.582 \\
(.056) \\
{[79]}\end{array}$ & $\begin{array}{l}.266 * * \\
\mathbf{( . 0 5 8 )}\end{array}$ \\
\hline $\begin{array}{l}\text { (B) Court Did Not } \\
\text { Apply Chevron }\end{array}$ & $\begin{array}{c}.875 \\
(.059) \\
{[32]}\end{array}$ & $\begin{array}{c}.647 \\
(.119) \\
{[17]}\end{array}$ & $\begin{array}{l}.228 * \\
(.119)\end{array}$ \\
\hline Difference of $(A)-(B)$ : & $\begin{array}{l}-.027 \\
(.070)\end{array}$ & $\begin{array}{l}-.065 \\
(.133)\end{array}$ & -- \\
\hline
\end{tabular}

II. Justices Kennedy and O'Connor

\begin{tabular}{lccc}
\hline & \multicolumn{3}{c}{ Ideological Content of Agency Decision } \\
\cline { 2 - 4 } Type of Analysis & Liberal & Not Liberal & $\begin{array}{c}\text { Difference of } \\
(1)-(2):\end{array}$ \\
\hline (A) Court Applied & .646 & .720 & $\mathbf{- . 0 7 4}$ \\
Chevron & $(.053)$ & $(.064)$ & $\mathbf{( . 0 8 5 )}$ \\
& {$[82]$} & {$[50]$} & \\
(B) Court Did Not & .389 & .333 & $\mathbf{. 0 5 6}$ \\
Apply Chevron & $(.118)$ & $(.142)$ & $\mathbf{( . 1 8 6 )}$ \\
& {$[18]$} & {$[12]$} & \\
Difference of (A)-(B): & $\mathbf{. 2 5 7 ^ { * * }}$ & $\mathbf{. 3 8 7 * *}$ & - \\
& $\mathbf{( . 1 2 6 )}$ & $\mathbf{( . 1 4 8 )}$ & \\
\hline
\end{tabular}

III. Justices Rehnquist, Scalia, and Thomas

\begin{tabular}{lccc}
\hline & \multicolumn{3}{c}{ Ideological Content of Agency Decision } \\
\cline { 2 - 4 } Type of Analysis & Liberal & Not Liberal & $\begin{array}{c}\text { Difference of } \\
(1)-(2):\end{array}$ \\
\hline (A) Court Applied & .455 & .761 & $\mathbf{- . 3 0 5} * *$ \\
Chevron & $(.045)$ & $(.051)$ & $\mathbf{( . 0 7 1 )}$ \\
& {$[123]$} & {$[71]$} & \\
(B) Court Did Not & .320 & .688 & $\mathbf{- . 3 6 8 * *}$ \\
Apply Chevron & $(.095)$ & $(.120)$ & $\mathbf{( . 1 5 3 )}$ \\
& {$[25]$} & {$[16]$} & \\
Difference of (A)-(B): & $\mathbf{. 1 3 5}$ & $\mathbf{. 0 7 3}$ & - \\
\hline
\end{tabular}

Note: * denotes difference significant at 10 percent level, and ** denotes difference significant at 5 percent level. Differences may not match exactly due to rounding. 
In sum, the evidence of Tables 5 and 6 does not provide unqualified support for either the doctrinal or the realist position. Table 6 shows that the validation rates of the political wings of the Court, the SSBG and RST groups, appear as ideological in non-Chevron cases as in Chevron cases. This finding is consistent with a simple realist view that the Chevron doctrine fails to constrain the political preferences of justices. However, Table 6 also reports that the validation rates of the SSBG are slightly lower-and those of the RST group are slightly higher-in Chevron cases than in non-Chevron cases. The validation rate of the $\mathrm{OK}$ group in Chevron cases is roughly 30 percentage points higher than in non-Chevron cases. Although the sample size is small, a doctrinalist might view these latter findings as consistent with Chevron encouraging, if not achieving, convergence in the validation rates of the justices. Again, the self-selected application of Chevron means that it is hazardous to infer its causal effect on validation rates simply by comparing outcomes in Chevron and non-Chevron cases. Table 5 shows that the frequency of Chevron application is itself difficult to interpret. A doctrinalist could contrast the modest ideological patterns in the rates of Chevron application with the strong ideological patterns in validation under Chevron and conclude that even ideologically motivated jurists are unable to escape the application of Chevron. The riposte of the realist is the application of Chevron matters little, given that Chevron does not succeed in dampening the ideological patterns in validation rates.

Because of the limited number of cases and because the Court has some discretion in deciding whether to apply Chevron, any generalizations must be tentative. But the evidence supports the view that among the most ideological justices, Chevron is not associated with increased validation of agency interpretations of law. In this respect, the data are quite inconsistent with the view, tempting to some doctrinalists, that Chevron and other deference doctrines should have a strong effect on judicial behavior. On the contrary, any effect of Chevron seems to be very modest.

\section{COURTS OF APPEALS AND CHEVRON}

It might be thought that for present purposes, the Supreme Court is unique. The Court decides the most difficult and controversial cases, and perhaps it is unsurprising to find that in those cases, political convictions matter in the application of the Chevron framework. On the courts of appeals, the effect of such convictions might be expected to be dampened. We now explore whether our conclusions about the Supreme Court's application of Chevron can be generalized by seeing whether the patterns persist in the courts of appeals. 


\section{A. Data and Method}

To isolate agency decisions that were likely to generate politically salient issues, attention was restricted to challenges to interpretations of law by two important agencies known for producing politically contentious decisions: the EPA and the NLRB. These data were structured into a file of judge-by-case observations, and we limit our attention in this analysis to cases in which the courts applied Chevron. The data set therefore contains a total of 680 votes -369 by Republican appointees and 311 by Democratic appointees. As with the Supreme Court, so too here: the coding decisions were simple and crude. We employ the same proxies of the ideological content of the agency decision: whether the decision was liberal or not, and the party of the current president.

In the Supreme Court, much is known about the individual justices, and the data themselves were largely consistent with these assessments. By contrast, circuit court judges are vastly greater in number and relatively less well known. To test for the effect of politics, we classified those judges according to the party of the president who nominated them to the circuit court. For ease of exposition, we refer to these judges as "Democratic appointees" or "Republican appointees.",

32 We originally collected the relevant data for the EPA, the NLRB, and the Federal Communications Commission (FCC), asking a group of research assistants to do the relevant coding. After they did their work, we collected the cases anew and recoded them ourselves for the EPA and the NLRB. The patterns we found were quite similar to those of the group of research assistants, with variations in the numbers but no substantial changes in the basic patterns. We also attempted to recode the FCC cases, but found the enterprise extremely difficult, in large part because of the number of parties and issues, and the consequent difficulty of characterizing FCC decisions in ideological terms. As a result of that difficulty, we dropped the FCC data from our analysis. Interestingly, however, the group of research assistants found patterns for the FCC that were entirely consistent with the basic patterns for the EPA and the NLRB - with validation rates that did not vary between Republican and Democratic appointees, but with voting patterns that showed an effect of ideology (higher validation rates by Republican appointees for Republican than Democratic administrations, and for conservative than liberal agency decisions, and the opposite patterns for Democratic appointees). The numbers here are available from the authors on request.

33 It is tempting and plausible to object to any claim that Republican appointees are "conservative" and that Democratic appointees are "liberal." But for purposes of analysis, it is not easy to develop simple, readily available alternatives for classifying judges. (Some efforts in this vein have been made. See generally, for example, Jennifer L. Peresie, Note, Female Judges Matter: Gender and Collegial Decisionmaking in the Federal Appellate Courts, 114 Yale L J 1759 (2005).) To the extent that our coding scheme misclassifies conservative judges as liberals and vice versa, these errors will reduce the likelihood that we detect differences in deference rates of the two groups. As we discern some patterns with this coding scheme, the error of misclassification is likely not too severe. 


\section{B. Summary Statistics}

Tables 7 and 8 display summary statistics on the validation rates in circuit courts, overall and stratified by the two measures of the ideological content of the agency decision. Column (1) of Table 7 reports the overall validation rates of Democratic and Republican appointees. We can readily see that the overall average validation rate of the circuit judges in Chevron cases, at about 64 percent, is roughly similar to that of the Supreme Court justices, which averaged 67 percent. Interestingly, the overall validation rates of Democratic and Republican appointees to the circuit courts are quite similar. The validation rate of the average Democratic appointee is higher than that of the average Republican appointee by only 0.03 of a percentage point, which is an insignificant difference.

\section{TABLE 7}

Validation Rates of Circuit Court Judges by Party of Appointing President in Chevron Cases:

Total and by Ideological Content of Agency Decision

(Means, Standard Errors in Parentheses, and Number of Observations in Brackets)

\begin{tabular}{|c|c|c|c|c|}
\hline \multirow[b]{2}{*}{$\begin{array}{l}\text { Party of Appointing } \\
\text { President }\end{array}$} & \multirow[b]{2}{*}{$\begin{array}{c}\text { Total } \\
\text { (1) }\end{array}$} & \multicolumn{3}{|c|}{ Ideological Content of Agency Decision } \\
\hline & & $\begin{array}{l}\text { Liberal } \\
\text { (2) }\end{array}$ & $\begin{array}{c}\text { Not Liberal } \\
\text { (3) }\end{array}$ & $\begin{array}{l}\text { Difference of } \\
(2)-(3) \text { : }\end{array}$ \\
\hline (A) Democratic & $\begin{array}{c}.640 \\
(.027) \\
{[311]}\end{array}$ & $\begin{array}{c}.739 \\
(.033) \\
{[176]}\end{array}$ & $\begin{array}{c}.511 \\
(.043) \\
{[135]}\end{array}$ & $\begin{array}{l}.228 * * \\
\mathbf{( . 0 5 4 )}\end{array}$ \\
\hline (B) Republican & $\begin{array}{c}.637 \\
(.025) \\
{[369]}\end{array}$ & $\begin{array}{l}.595 \\
(.033) \\
{[220]}\end{array}$ & $\begin{array}{c}.698 \\
(.038) \\
{[149]}\end{array}$ & $\begin{array}{l}-.103 * * \\
(.051)\end{array}$ \\
\hline Difference of $(A)-(B)$ & $\begin{array}{r}.003 \\
(.037)\end{array}$ & $\begin{array}{l}.143 * * \\
(.048)\end{array}$ & $\begin{array}{l}-.187 * * \\
(.057)\end{array}$ & -- \\
\hline
\end{tabular}

Note: * denotes difference significant at 10 percent level, and ** denotes difference significant at 5 percent level. Differences may not match exactly due to rounding.

The next columns of Table 7 break out the validation rates by whether the agency decision is liberal or not. These decompositions show that the overall validation rates mask significant correlations between the political party of the appointing president and the ideological content of the agency decision. When the agency decision is liberal, the validation rates of Democratic appointees are almost 23 percentage points higher, and those of Republican appointees are more than 10 percentage points lower. Although the Democratic appointees appear somewhat more responsive to the political content of the case, the difference across the two types of judges (that is, $12.5=22.8-10.3$ ) is not so 
great that it permits a conclusion that the validation rates of judges of one party fluctuate by more-in a statistical sense-than those of judges of the other party. Instead, the validation rates of all circuit judges display an almost seesawing pattern according to the identity of the challenging party.

A notable difference between the patterns observed here and those among the Supreme Court justices is that the magnitude of the fluctuation in the validation rates between liberal and nonliberal agency decisions is about 10 percentage points lower among the circuit court judges. The validation rates in cases involving liberal agency actions appear to account for most of this difference. The validation rates of Democratic appointees in cases with liberal agency decisions do not rise as high as those of the SSBG group, and the validation rates of Republican appointees in these cases do not fall as low as those of the RST group. The less prominent ideological pattern in the circuit court data may be due to our less precise measures of the judicial ideology of circuit court judges. The use of the political party of the nominating president is an imperfect measure because some conservative judges were nominated by Democratic presidents, just as some liberal judges were nominated by Republican presidents. Even with this crude measure, these results provide further support for the realist hypothesis.

TABLE 8

Validation Rates of Circuit Court Judges by Party of Appointing and by Current President in Chevron Cases (Means, Standard Errors in Parentheses, and Number of Observations in Brackets)

\begin{tabular}{|c|c|c|c|c|}
\hline \multirow[b]{2}{*}{$\begin{array}{l}\text { Party of Appointing } \\
\text { President }\end{array}$} & \multirow[b]{2}{*}{$\begin{array}{c}\text { Total } \\
\text { (1) }\end{array}$} & \multicolumn{3}{|c|}{ Party of Current President } \\
\hline & & $\begin{array}{c}\text { Democratic } \\
\text { (2) }\end{array}$ & $\begin{array}{l}\text { Republican } \\
\text { (3) }\end{array}$ & $\begin{array}{l}\text { Difference of } \\
\text { (2)-(3): }\end{array}$ \\
\hline (A) Democratic & $\begin{array}{l}.640 \\
(.027) \\
{[311]}\end{array}$ & $\begin{array}{c}.698 \\
(.043) \\
{[116]}\end{array}$ & $\begin{array}{c}.605 \\
(.035) \\
{[195]}\end{array}$ & $\begin{array}{l}.093 * \\
\mathbf{( . 0 5 6 )}\end{array}$ \\
\hline (B) Republican & $\begin{array}{c}.637 \\
(.025) \\
{[369]}\end{array}$ & $\begin{array}{c}.592 \\
(.038) \\
{[169]}\end{array}$ & $\begin{array}{c}.675 \\
(.033) \\
{[200]}\end{array}$ & $\begin{array}{l}-.083 * \\
(.050)\end{array}$ \\
\hline Difference of (A)-(B) & $\begin{array}{l}.003 \\
(.037)\end{array}$ & $\begin{array}{l}.107 * \\
\text { (.058) }\end{array}$ & $\begin{array}{l}-.070 \\
(.048)\end{array}$ & -- \\
\hline
\end{tabular}

Note: * denotes difference significant at 10 percent level, and ** denotes difference significant at 5 percent level. Differences may not match exactly due to rounding.

Table 8 reports validation rates when the party of the current president is the proxy for the ideological content of the agency decision. The pattern for Republican nominees here is similar to that in 
the prior table, but the validation rates of Democratic nominees exhibit less movement here-about 9 percentage points rather than the 23 percentage points shown in Table 7. As was seen with the Supreme Court justices, the party of the current president is probably a less accurate measure of the ideological content of an agency decision. Although the amplitude of the fluctuations is reduced here, the seesawing pattern that is consistent with the realist hypothesis persists.

In sum, the results for the circuit courts, like those for the Supreme Court, provide strong evidence that the political predispositions of the judges influence the judicial review of agency interpretations. ${ }^{34}$ Overall, Democratic appointees validate at roughly the same rate as the Republican appointees. These overall figures obscure correlations between a judge's political party and the ideological content of the agency interpretations. When the cases are classified according to whether the agency decision is liberal, the validation rates of both Republican and Democratic appointees exhibit a strong seesawing pattern, with validation rates of the judges of each party rising when the content of the agency decision is closer to their political preference.

When the data are decomposed by the party of the current president, a similar but less pronounced pattern is apparent. When a Democrat rather than a Republican occupies the presidency, the validation rates of Republican appointees fall by about 8 percentage points and those of Democratic appointees rise by about 9 percentage points. Therefore, when a Democrat is president, the validation rates of Republican appointees are on average lower than those of Democratic appointees, and when a Republican is president the opposite is true. The results for circuit court judges thus provide support for the realist model, but as with the Supreme Court justices, it is far from a complete explanation, simply because judicial politics cannot account for all of the patterns that we observe.

\section{Chevron Review in Circuit Courts: The Power of Panels}

Across a range of legal issues in which ideology is expected to play a role, a federal circuit judge has been found to be more likely to vote in a predictably ideological way when sitting on a panel with two judges appointed by a president of the same political party. For con-

\footnotetext{
34 Again, we used regression analysis to examine the robustness of these patterns to other factors potentially bearing on the likelihood that a judge votes to defer. We forgo discussion of those estimates here, except to say that the patterns apparent in the summary statistics are robust to controlling for the dates, the circuit court, and type of agency involved in the case.

35 See Cass R. Sunstein, David Schkade, and Lisa Michelle Ellman, Ideological Voting on Federal Courts of Appeals: A Preliminary Investigation, 90 Va L Rev 301, 305, 316-29 (2004) (noting that "Democratic appointees, sitting with two Democratic appointees, are about twice as
} 
venience, we refer to these correlations between politicized voting and panel composition as "panel effects."

This subsection examines the latter mechanism more fully. Focusing on the data from the courts of appeals, we test whether panel effects persist in cases where a circuit court applied Chevron. ${ }^{36}$ The most important lesson is that both Democratic and Republican appointees show far more political voting patterns when they are sitting on unified panels. When the panels are divided, the role of politics is greatly dampened.

\section{FIGURE 1}

Validation Rates of Circuit Judges in Chevron Cases, by Agency and by Party of Appointing President

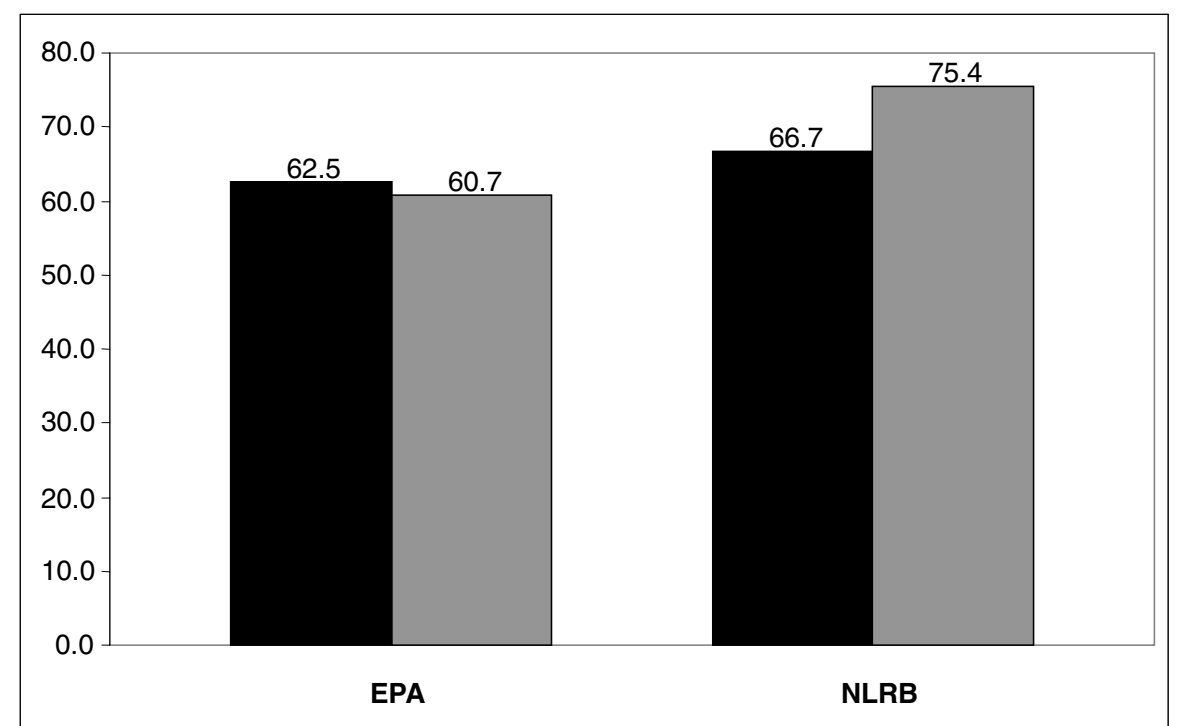

Note: The darkly shaded bars indicate the validation rates of Republican appointees, and the lightly shaded bars indicate the validation rates of Democratic appointees.

likely to vote in the stereotypically liberal fashion as are Republican appointees, sitting with two Republican appointees").

36 The analysis differs from that of Sunstein, Schkade, and Ellman, 90 Va L Rev 301 (cited in note 35), in several important respects. The earlier analysis examined the role of panel composition in cases involving controversial issues that were "especially likely to reveal divisions between Republican and Democratic appointees," such as affirmative action and campaign finance. Id at 304. In contrast, Chevron is intended to reduce, even minimize, divisions between Republican and Democratic appointees. Although the Sunstein et al study examined EPA cases, it considered only an expanded version of Richard Revesz's sample of EPA cases from the D.C. Circuit. See id at 322-23, 345-47 (discussing the sample used); Richard L. Revesz, Environmental Regulation, Ideology, and the D.C. Circuit, 83 Va L Rev 1717 (1997) (examining the impact of judges' ideology on judicial decisionmaking on the D.C. Circuit in environmental cases). The current data includes EPA - as well as NLRB and FCC cases - from all circuits. 
Figures 1 and 2 present basic facts about validation rates. Figure 1 shows validation rates by the agency and by the party of the judge's appointing president. When the judges' votes are not decomposed by political affiliation, the overall validation rates by agency vary relatively little: for the EPA and NLRB, those rates are 61.7 percent and 70.1 percent, respectively. Figure 1 also shows small differences across the party of the judge's appointing president within each type of case. These modest differences are consistent with the near equivalence in the validation rates of Democratic and Republican appointees overall in Table 7 . The validation rates of Republican and Democratic appointees in EPA cases differ by less than 2 percentage points, though in NLRB cases, Democratic appointees validate at a rate nearly 9 percentage points higher than Republican appointees.

\section{FIGURE 2}

Validation Rates of Circuit Judges in Chevron Cases, by Panel Composition and by Party of Appointing President

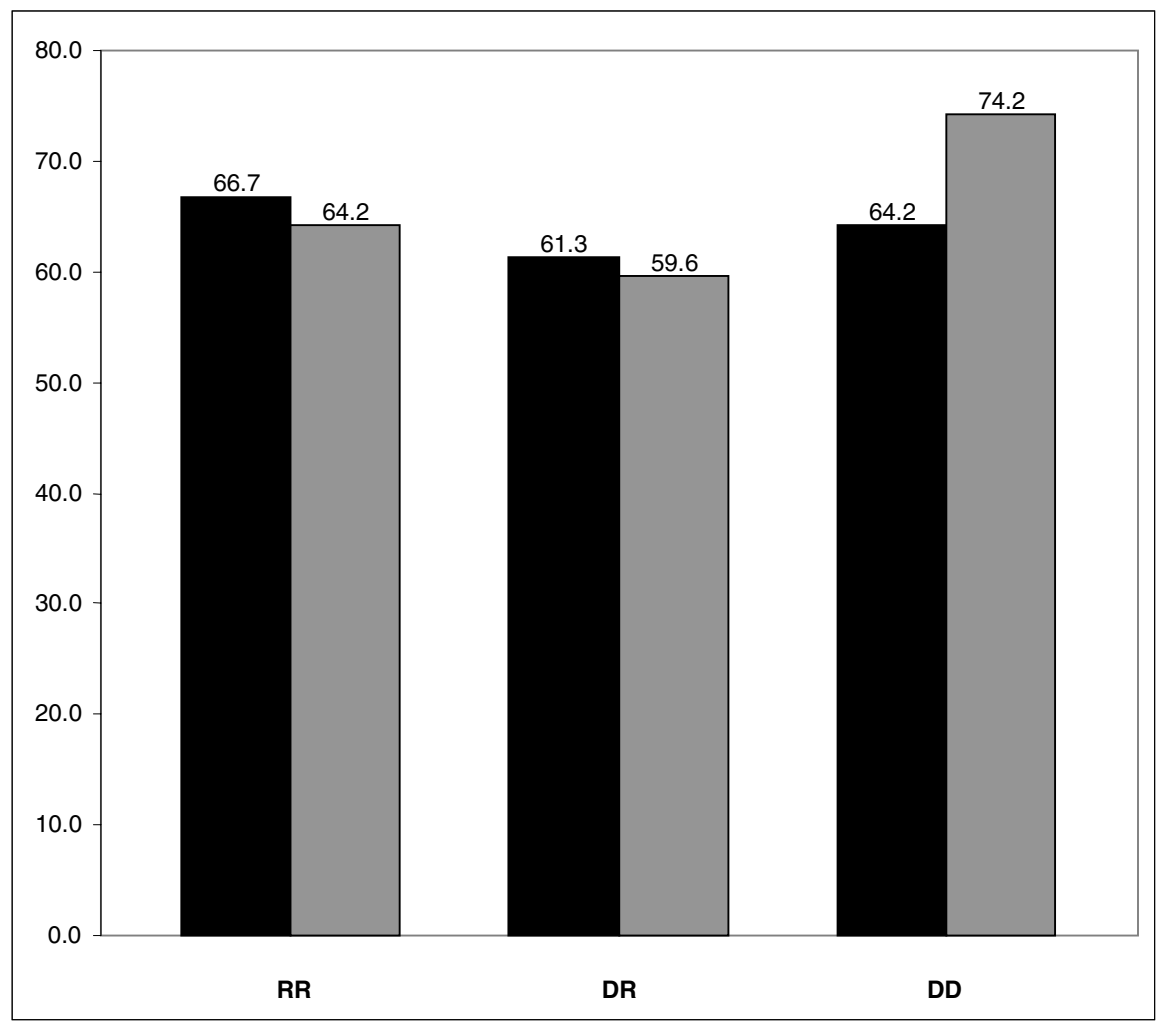

Note: The darkly shaded bars indicate the validation rates of Republican appointees, and the lightly shaded bars indicate the validation rates of Democratic appointees. 
These patterns conform to general impressions of the contentiousness of the issues confronting these agencies. The NLRB has the wider validation gap between judges of different political parties, and labor-management relations are traditionally a subject in which views align along the conventional left-right spectrum. Environmental issues may be slightly less polarizing. Consistent with this impression, the validation rates of Democratic and Republican appointees are nearly identical in EPA cases.

Figure 2 displays the validation rates of court of appeals judges by the political composition of the appellate panel. This figure pools the cases pertaining to all three agencies. Two patterns are striking. First, a moderate panel effect characterizes Democratic appointees. When sitting with either one or two Republican appointees, a Democratic appointee validates about 61 percent of the time. Moreover, in that circumstance, the validation rate of the Democratic appointee is indistinguishable from that of her Republican colleagues. But when sitting with two other Democrats, the average validation rate of a Democratic appointee jumps by more than 12 percentage points. Prior research established that across a broad range of issues, ideological voting increases with the addition of any like-minded judge to a panel. In this sample of Chevron cases, strong ideological patterns in voting emerge only when all three judges on a panel belong to the same party.

Second, the overall validation rates of Republican appointees appear nearly invariant to panel composition. Their validation rates range from about 61 percent to 67 percent - a movement of only 6 percentage points. These estimates contrast with earlier findings that, for judges of both political parties, the frequency with which they voted in stereotypically ideological ways correlated with the composition of the panel.

As with several of the Supreme Court justices, stability in overall validation rates could mask substantial variation in validation when the ideological content of the agency decision is examined. Therefore, the validation rates were further decomposed by our two proxies for the political content of the agency decision. Tables 9 and 10 present these decompositions. In Table 9, the cases were classified according to whether the agency decision was liberal, and in Table 10, they were

37 See Sunstein, Schkade, and Ellman, 90 Va L Rev at 316-29 (cited in note 35) (showing that party and panel influences on the votes of individual judges obtain in a number of issue areas).

38 In the overall deference rates displayed in Figure 2, this pattern is apparent only for Democratic appointees. But when the data are also stratified by political content of the agency decision, as in Tables 9 and 10, this pattern characterizes Republican appointees as well.

39 See Sunstein, Schkade, and Ellman, 90 Va L Rev at 316-29 (cited in note 35) (demonstrating that the rates of ideological votes by Republican judges differed by 14 percentage points, depending on the composition of the panel). 
classified according to whether the current president was a Democrat or Republican. The results are remarkably consistent across these two classifications, and here the role of panel effects becomes more striking.

\section{TABLE 9}

Validation Rates in Chevron Cases by Party of Appointing President, by Ideological Content of Agency Decision, and by Panel Composition (Means, Standard Errors in Parentheses, and Number of Observations in Brackets)

\begin{tabular}{|c|c|c|c|c|c|}
\hline \multirow[b]{2}{*}{$\begin{array}{l}\text { Party of Appointing } \\
\text { President }\end{array}$} & \multirow[b]{2}{*}{$\begin{array}{c}\text { Panel } \\
\text { Composition }\end{array}$} & \multirow[b]{2}{*}{ Total } & \multicolumn{3}{|c|}{ Ideological Content of Agency Decision } \\
\hline & & & $\begin{array}{c}\text { Liberal } \\
\text { (1) }\end{array}$ & $\begin{array}{c}\text { Not Liberal } \\
\text { (2) }\end{array}$ & $\begin{array}{l}\text { Difference of } \\
\text { (1)-(2): }\end{array}$ \\
\hline (A) Democratic & DDD & $\begin{array}{c}.742 \\
(.054) \\
{[66]}\end{array}$ & $\begin{array}{c}.857 \\
(.055) \\
{[42]}\end{array}$ & $\begin{array}{c}.542 \\
(.104) \\
{[24]}\end{array}$ & $\begin{array}{c}\mathbf{. 3 1 5} * * \\
\mathbf{( . 1 0 7 )}\end{array}$ \\
\hline (B) Democratic & $\begin{array}{l}\text { DDR or } \\
\text { RRD }\end{array}$ & $\begin{array}{c}.612 \\
(.031) \\
{[245]}\end{array}$ & $\begin{array}{l}.701 \\
(.040) \\
{[134]}\end{array}$ & $\begin{array}{c}.505 \\
(.048) \\
{[111]}\end{array}$ & $\begin{array}{l}.197 * * * \\
(.062)\end{array}$ \\
\hline (C) Republican & $\begin{array}{l}\text { DDR or } \\
\text { RRD }\end{array}$ & $\begin{array}{c}.622 \\
(.031) \\
{[249]}\end{array}$ & $\begin{array}{l}.647 \\
(.041) \\
{[139]}\end{array}$ & $\begin{array}{c}.591 \\
(.047) \\
{[110]}\end{array}$ & $\begin{array}{c}.057 \\
(.062)\end{array}$ \\
\hline (D) Republican & RRR & $\begin{array}{c}.667 \\
(.043) \\
{[120]}\end{array}$ & $\begin{array}{c}.506 \\
(.056) \\
{[81]}\end{array}$ & $\begin{array}{c}1.000 \\
(.000) \\
{[39]}\end{array}$ & $\begin{array}{c}-.494 * * \\
(.081)\end{array}$ \\
\hline Difference of (A)-(B): & -- & $\begin{array}{l}.130 * \\
(.066)\end{array}$ & $\begin{array}{l}.156 * * \\
(.077)\end{array}$ & $\begin{array}{c}.037 \\
(.113)\end{array}$ & -- \\
\hline Difference of (A)-(C): & -- & $\begin{array}{l}.112 * \\
(.066)\end{array}$ & $\begin{array}{l}.210 * * \\
(.080)\end{array}$ & $\begin{array}{l}-.049 \\
(.112)\end{array}$ & -- \\
\hline Difference of (A)-(D): & -- & $\begin{array}{l}.076 \\
(.071)\end{array}$ & $\begin{array}{l}. \mathbf{3 5 1} * * \\
\mathbf{( . 0 8 7 )}\end{array}$ & $\begin{array}{c}-.458 * * \\
(.081)\end{array}$ & -- \\
\hline Difference of (B)-(C): & -- & $\begin{array}{c}-.010 \\
(.044)\end{array}$ & $\begin{array}{c}.054 \\
(.057)\end{array}$ & $\begin{array}{l}-.086 \\
(.067)\end{array}$ & -- \\
\hline Difference of (B)-(D): & -- & $\begin{array}{r}-.054 \\
(.054)\end{array}$ & $\begin{array}{l}.195^{* * *} \\
(.067)\end{array}$ & $\begin{array}{c}-.495^{* * *} \\
(.081)\end{array}$ & -- \\
\hline Difference of (C)-(D): & -- & $\begin{array}{r}-.044 \\
(.054)\end{array}$ & $\begin{array}{l}.141^{* *} \\
(.068)\end{array}$ & $\begin{array}{l}-.409 * * \\
(.079)\end{array}$ & -- \\
\hline
\end{tabular}

Note: * denotes difference significant at 10 percent level, and ** denotes difference significant at 5 percent level. Differences may not match exactly due to rounding.

In Table 9, the validation rates of Democrats who sit on panels with two other Democratic appointees are nearly a mirror image of those of Republican appointees who sit on panels with two other Republican appointees. These fine decompositions of the sample reduce the number of observations and make it difficult to make firm inferences about magnitudes, but strong patterns emerge. Here is the most 
striking finding: a Democratic appointee sitting with two Democratic appointees votes to uphold a liberal decision more than 30 percentage points more often than a conservative one-and a Republican appointee sitting with two Republican appointees votes to uphold a conservative decision more than 30 percentage points more often than a liberal one. For both Republican and Democratic appointees, the validation rates rise from about 50 percent when the judge's party affiliation does not match the political content of the agency decision to over 80 percent when it does match.

When judges sit on panels with at least one judge of the other party, the political content of the agency decision appears to induce much less fluctuation in the validation rates. A Democratic appointee sitting on a panel with either one or two Republican appointees is about 20 percentage points more likely to vote to validate when the agency decision is liberal. A Republican appointee sitting on a panel with either one or two Democratic appointees is only about 6 percentage points less likely to vote to validate when the agency decision is liberal. Politically mixed panels therefore dampen the size of ideological fluctuations in validation rates.

Table 10 presents analogous calculations when the cases are organized by the party of the current president. The patterns here are similar and in a way stunning. A Democratic appointee sitting with two other Democrats votes to validate about 30 percentage points less often when the president is a Republican than when he is a Democrat. A Republican appointee sitting with two other Republican appointees votes to validate about 30 percentage points less often when the president is a Democrat than when he is Republican. 


\section{TABLE 10}

Validation Rates in Chevron Cases by Party of Appointing President, by Party of Current President, and by Panel Composition

(Means, Standard Errors in Parentheses, and Number of Observations in Brackets)

\begin{tabular}{|c|c|c|c|c|}
\hline \multirow[b]{2}{*}{$\begin{array}{l}\text { Party of Appointing } \\
\text { President }\end{array}$} & \multirow[b]{2}{*}{$\begin{array}{c}\text { Panel } \\
\text { Composition }\end{array}$} & \multicolumn{3}{|c|}{ Party of Current President } \\
\hline & & $\begin{array}{c}\text { Democratic } \\
\text { (1) }\end{array}$ & $\begin{array}{c}\text { Republican } \\
\text { (2) }\end{array}$ & $\begin{array}{l}\text { Difference of } \\
(1)-(2) \text { : }\end{array}$ \\
\hline (A) Democratic & DDD & $\begin{array}{c}.952 \\
(.048) \\
{[21]}\end{array}$ & $\begin{array}{c}.644 \\
(.072) \\
{[45]}\end{array}$ & $\begin{array}{l}.308 * * \\
(.111)\end{array}$ \\
\hline (B) Democratic & $\begin{array}{l}\text { DDR or } \\
\text { RRD }\end{array}$ & $\begin{array}{c}.642 \\
(.049) \\
{[95]}\end{array}$ & $\begin{array}{l}.593 \\
(.040) \\
{[150]}\end{array}$ & $\begin{array}{l}.049 \\
(.064)\end{array}$ \\
\hline (C) Republican & $\begin{array}{l}\text { DDR or } \\
\text { RRD }\end{array}$ & $\begin{array}{l}.632 \\
(.047) \\
{[106]}\end{array}$ & $\begin{array}{l}.615 \\
(.041) \\
{[143]}\end{array}$ & $\begin{array}{l}.017 \\
(.062)\end{array}$ \\
\hline (D) Republican & RRR & $\begin{array}{c}.524 \\
(.063) \\
{[63]}\end{array}$ & $\begin{array}{c}.825 \\
(.051) \\
{[57]}\end{array}$ & $\begin{array}{l}-.301 * * \\
(.082)\end{array}$ \\
\hline Difference of (A)-(B): & -- & $\begin{array}{l}.310 * * \\
(.108)\end{array}$ & $\begin{array}{l}.051 \\
(.083)\end{array}$ & -- \\
\hline Difference of $(A)-(C)$ : & -- & $\begin{array}{l}.320 * * \\
(.108)\end{array}$ & $\begin{array}{l}.029 \\
(.083)\end{array}$ & -- \\
\hline Difference of (A)-(D): & -- & $\begin{array}{l}.429 * * \\
(.114)\end{array}$ & $\begin{array}{l}-.180 * * \\
(.086)\end{array}$ & -- \\
\hline Difference of $(B)-(C)$ : & -- & $\begin{array}{l}.010 \\
(.068)\end{array}$ & $\begin{array}{l}-.022 \\
(.057)\end{array}$ & -- \\
\hline Difference of (B)-(D): & -- & $\begin{array}{l}.118 \\
(.080)\end{array}$ & $\begin{array}{l}-.231 * * \\
(.072)\end{array}$ & -- \\
\hline Difference of (C)-(D): & -- & $\begin{array}{c}.108 \\
(.078)\end{array}$ & $\begin{array}{l}-.209 * * \\
(.072)\end{array}$ & -- \\
\hline
\end{tabular}

Note: * denotes difference significant at 10 percent level, and ** denotes difference significant at 5 percent level. Differences may not match exactly due to rounding.

The first column of Table 9 shows that for judges sitting on mixed panels, the overall validation rates of Democratic and Republican appointees are nearly identical-61 and 62 percent, respectively. The patterns are less clear, however, when the validation rates of Democratic and Republican appointees sitting on mixed panels are further broken out by the measures for the ideological content of the agency decision. Table 9 shows that especially for Democratic appointees, the validation rates of judges sitting on politically mixed panels exhibit 
some sensitivity to the political content of the agency decision. Democratic appointees sitting on mixed panels vote to validate about 20 percentage points more often when the agency decision is liberal rather than conservative, but this difference is still less than that of Democratic appointees sitting with two other Democratic appointees. Republican appointees sitting on mixed panels vote to validate nonliberal agency decisions about 6 percentage points more often than liberal ones. In contrast, Table 10 reports that the validation rates of Democratic and Republican appointees sitting on mixed panels appear invariant to the party of the current president. These results indicate that the pattern of ideological voting by judges sitting on politically unified panels is robust to either measure of the political content of the agency decision. In contrast, the pattern of ideological voting by judges sitting on politically mixed panels appears muted in Table 9 and disappears altogether in Table $10 .^{40}$

These estimates show that, consistent with prior research, panel composition has a sizable effect on judicial voting patterns. But the influence of panel composition has a somewhat more limited effect in Chevron cases than it does in the consideration of other legal issues. Prior research showed that for many ideologically contentious issues, panel composition influenced the likelihood that judges vote in predictably ideological ways, even when the panels were a mix of Republicans and Democrats. In contrast, when a court applies Chevron's two-step framework, ideological tendencies in overall deference rates appear restricted to appellate panels composed of three judges from the same political party. The addition of even just one judge from the other political party renders overall validation rates of Democratic and Republican appointees nearly indistinguishable. Whether it also eliminates fluctuation in validation rates across the political content of agency decisions for judges sitting on politically mixed panels is unclear; these estimates are sensitive to which measure of political content is used.

These estimates suggest that most of the difference in the validation rates of Republican and Democratic appointees arises from panels consisting exclusively of judges from one political party. For politically mixed panels, the validation rates of Democratic and Republican judges are very similar to each other; all but one of the differences are 10 percentage points or less and are statistically insignificant. The only

40 The regression analysis was used to verify the robustness of the patterns reported in Tables 7 through 10 to the control variables already discussed in note 34 . We forgo reporting those results in detail, except to express our confidence that the patterns we discuss here persist after controlling for those other factors.

41 See Sunstein, Schkade, and Ellman, 90 Va L Rev at 316-29 (cited in note 35). 
exception to this pattern is that a Democratic judge on a politically mixed panel has a validation rate 20 percentage points higher when the agency decision is liberal rather than conservative. Even this difference, however, appears modest when compared to the differences of more than 30 percentage points for politically unified panels. It follows that when a circuit court applies Chevron, the influence of panel composition on judicial decisionmaking appears largely cabined to politically unified panels. These patterns suggest the possibility that Chevron is succeeding in eliminating the influence of circuit judges' political preferences in review of agency decisions, at least within the domain of politically mixed panels.

\section{Liberal and Conservative Voting}

As with the Supreme Court, we reclassified the data in terms of liberal and conservative voting, and similar patterns emerged, perhaps in even more striking form.

\section{TABLE 11}

Liberal Vote Rates of Circuit Court Appointees by Party of Appointing President and by Current President in Chevron Cases (Means, Standard Errors in Parentheses, and Number of Observations in Brackets)

\begin{tabular}{lcccc}
\hline & & \multicolumn{3}{c}{ Party of Current President } \\
\cline { 3 - 5 } $\begin{array}{l}\text { Party of Appointing } \\
\text { President }\end{array}$ & $\begin{array}{c}\text { Total } \\
\text { (A) Democratic }\end{array}$ & $\begin{array}{c}\text { Democratic } \\
(1)\end{array}$ & $\begin{array}{c}\text { Republican } \\
(3)\end{array}$ & $\begin{array}{c}\text { Difference of } \\
(2)-(3):\end{array}$ \\
\hline & .672 & .716 & .646 & $\mathbf{. 0 6 9}$ \\
& {$[.027)$} & $(.042)$ & $(.034)$ & $\mathbf{( . 0 5 5 )}$ \\
(B) Republican & {$[311]$} & {$[116]$} & {$[195]$} & \\
& .499 & .473 & .520 & $\mathbf{- . 0 4 7}$ \\
Difference of (A)-(B): & $(.026)$ & $(.039)$ & $(.035)$ & $\mathbf{( . 0 5 2 )}$ \\
& {$[369]$} & {$[169]$} & {$[200]$} & \\
& $\mathbf{. 1 7 3} * *$ & $\mathbf{. 2 4 2} * *$ & $\mathbf{. 1 2 6} * *$ & $\mathbf{- -}$
\end{tabular}

Note: * denotes difference significant at 10 percent level, and ** denotes difference significant at 5 percent level. Differences may not match exactly due to rounding.

Table 11 presents rates of liberal voting for Democratic and Republican appointees overall and by the party of the current president. Column (1) of Table 11 shows that, consistent with expectations, Democratic appointees are 17 percentage points more likely to offer a liberal vote in Chevron cases, and this difference is statistically significant.

The remaining columns of Table 11 show that the rates of liberal voting vary modestly with political control of the White House. Democratic appointees are about 7 percentage points more likely to vote 
in a liberal way when a Democrat holds the presidency, and Republicans are about 5 percentage points less likely to vote in a liberal way when a Republican serves as president. These differences imply that when a Democrat is president, the average Democratic appointee votes in a liberal way about 24 percentage points more often than the average Republican appointee does. But even during a Republican presidency, the higher rate of liberal voting by Democratic appointees - by nearly 13 percentage points - is statistically different from the rate of liberal voting of Republican appointees.

\section{FIGURE 3}

Liberal Voting Rates of Circuit Judges in Chevron Cases, by Panel Composition and by Party of Appointing President

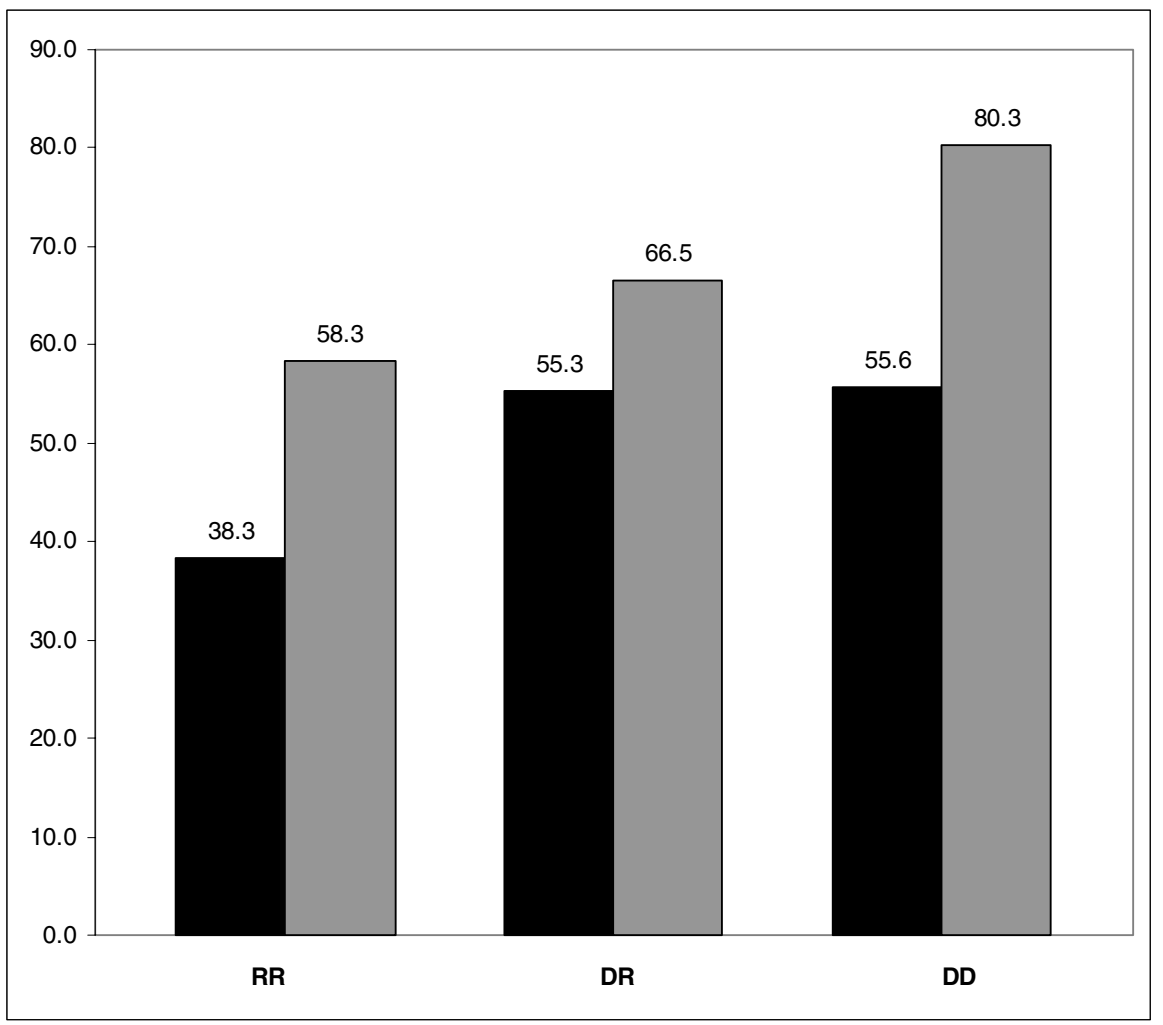

Note: The darkly shaded bars indicate the validation rates of Republican appointees, and the lightly shaded bars indicate the validation rates of Democratic appointees.

Figure 3 examines liberal voting rates of circuit judges in Chevron cases by the political composition of the appellate panel. In contrast to the validation rates shown in Figure 2, a strong panel effect characterizes both Democratic and Republican appointees. Although some of the differences are modest, both Republican and Democratic appoint- 
ees are more likely to vote in a liberal way as the number of Democratic appointees on the panel rises. This increase in rates of liberal voting occurs across all panels and, unlike the pattern seen in the validation rates, is not limited to the panels comprised only of Democratic appointees.

Even in the presence of these panel effects, Democratic appointees appear more liberal than their Republican counterparts sitting on similarly constituted panels. Even in the politically mixed panels that featured similar validation rates by Democratic and Republican appointees, sizable differences in liberal voting rates are present. The difference in the liberal voting rate between Democratic appointees sitting with one Democratic and one Republican appointee (66.5 percent), and that of Republican appointees also sitting with one Democratic and one Republican appointee (55.3 percent) is statistically different from zero. For every combination of panel colleagues, the Democratic appointee is more likely to cast a liberal vote than a Republican appointee is by at least 10 percentage points, and each of these differences is statistically different from zero.

Table 12 decomposes the rates of liberal voting by the political makeup of the appellate panel and by the party of the current president. Consistent with previous tables, the voting patterns of politically unified panels account for much of the difference in the aggregate liberal voting rates of Democratic and Republican appointees. As reported in column (1) of Table 12, a Democratic appointee sitting with two other Democratic appointees on average votes in the liberal way 17 percentage points more often than when she sits with at least one Republican. For Republican appointees, this pattern is reversed. A Republican appointee sitting with two other Republican appointees on average votes in the liberal way 17 percentage points less often than when she sits with least one Democrat. Here is the most striking finding: there is a gap of about 40 percentage points in liberal voting rates between the votes of Democratic appointees on exclusively Democratic panels and those of Republican appointees on exclusively Republican panels. 
TABLE 12

Liberal Voting Rates in Chevron Cases by Party of Appointing President, by Party of Current President, and by Panel Composition (Means, Standard Errors in Parentheses, and Number of Observations in Brackets)

\begin{tabular}{|c|c|c|c|c|c|}
\hline \multirow[b]{2}{*}{$\begin{array}{l}\text { Party of Appointing } \\
\text { President }\end{array}$} & \multirow[b]{2}{*}{$\begin{array}{c}\text { Panel } \\
\text { Composition }\end{array}$} & \multirow[b]{2}{*}{$\begin{array}{l}\text { Total } \\
\text { (1) }\end{array}$} & \multicolumn{3}{|c|}{ Party of Current President } \\
\hline & & & $\begin{array}{l}\text { Democratic } \\
\text { (2) }\end{array}$ & $\begin{array}{c}\text { Republican } \\
\text { (3) }\end{array}$ & $\begin{array}{l}\text { Difference } \\
\text { of (2)-(3): }\end{array}$ \\
\hline (A) Democratic & DDD & $\begin{array}{c}.803 \\
(.049) \\
{[66]}\end{array}$ & $\begin{array}{c}.762 \\
(.095) \\
{[21]}\end{array}$ & $\begin{array}{c}.822 \\
(.058) \\
{[45]}\end{array}$ & $\begin{array}{l}-.060 \\
(.106)\end{array}$ \\
\hline (B) Democratic & $\begin{array}{l}\text { DDR or } \\
\text { RRD }\end{array}$ & $\begin{array}{c}.637 \\
(.031) \\
{[245]}\end{array}$ & $\begin{array}{c}.705 \\
(.047) \\
{[95]}\end{array}$ & $\begin{array}{c}.593 \\
(.040) \\
{[150]}\end{array}$ & $\begin{array}{l}.112 * * \\
(.063)\end{array}$ \\
\hline (C) Republican & $\begin{array}{l}\text { DDR or } \\
\text { RRD }\end{array}$ & $\begin{array}{c}.554 \\
(.032) \\
{[249]}\end{array}$ & $\begin{array}{l}.585 \\
(.048) \\
{[106]}\end{array}$ & $\begin{array}{c}.531 \\
(.042) \\
{[143]}\end{array}$ & $\begin{array}{l}.053 \\
(.064)\end{array}$ \\
\hline (D) Republican & RRR & $\begin{array}{c}.383 \\
(.045) \\
{[120]}\end{array}$ & $\begin{array}{c}.286 \\
(.057) \\
{[63]}\end{array}$ & $\begin{array}{c}.491 \\
(.067) \\
{[57]}\end{array}$ & $\begin{array}{l}-.206 * * \\
(.088)\end{array}$ \\
\hline Difference of (A)-(B): & -- & $\begin{array}{l}.166 * * \\
(.065)\end{array}$ & $\begin{array}{l}.057 \\
(.110)\end{array}$ & $\begin{array}{l}.229 * * \\
(.080)\end{array}$ & -- \\
\hline Difference of (A)-(C): & -- & $\begin{array}{l}.249 * * \\
(.067)\end{array}$ & $\begin{array}{l}.117 \\
(.116)\end{array}$ & $\begin{array}{l}.291 * * \\
(.081)\end{array}$ & -- \\
\hline Difference of (A)-(D): & -- & $\begin{array}{l}.420 * * \\
(.070)\end{array}$ & $\begin{array}{l}.476 * * \\
(.114)\end{array}$ & $\begin{array}{l}.331 * * \\
(.091)\end{array}$ & -- \\
\hline Difference of (B)-(C): & -- & $\begin{array}{l}.082 * \\
(.044)\end{array}$ & $\begin{array}{l}.120 * * \\
(.068)\end{array}$ & $\begin{array}{l}.062 \\
(.058)\end{array}$ & -- \\
\hline Difference of (B)-(D): & -- & $\begin{array}{l}.253 * * \\
(.054)\end{array}$ & $\begin{array}{l}.419 * * \\
(.074)\end{array}$ & $\begin{array}{l}.102 \\
(.077)\end{array}$ & -- \\
\hline Difference of (C)-(D): & -- & $\begin{array}{l}.171 * * \\
(.058)\end{array}$ & $\begin{array}{l}.229 * * \\
(.076)\end{array}$ & $\begin{array}{c}.040 \\
(.079)\end{array}$ & -- \\
\hline
\end{tabular}

Note: * denotes difference significant at 10 percent level, and ** denotes difference significant at 5 percent level. Differences may not match exactly due to rounding.

The rest of Table 12 indicates that, after controlling for the composition of the appellate panel, the party of the current president correlates inconsistently with liberal voting rates. The liberal voting rates of Republican appointees sitting on politically unified panels correlate strongly with the party of the current president, but the liberal voting rates of Democratic appointees sitting on politically unified panels do not. For a Republican appointee on a politically mixed panel, a change in the party of the presidency implies a movement in the rate of lib- 
eral voting of about 5 percentage points. For a Democratic appointee on a politically mixed panel, this fluctuation is about 11 percentage points.

\section{E. Mixed Panels and Unified Panels Once More}

We have found that judges show much more ideological voting on politically unified panels, and that this pattern explains many of the ideological tendencies observed in the aggregate data. But the comparisons across panels establish four specific findings that are worth underlining here. First, the composition of appellate panels has a much greater effect on rates of liberal voting than on rates of votes to validate. This distinction is clear in a comparison of Figure 2 to Figure 3, as well as Tables 9 and 10 to Table 12 .

Second, when ideological voting appears, it is concentrated in politically unified panels. In Tables 9 and 10, the validation rates of Republican appointees sitting on politically mixed panels are insensitive to either measure of the ideological content of the agency action. On mixed panels, then, Republican appointees simply do not show ideological voting. The pattern is not consistent for Democratic appointees. When our coding of the ideological content of the agency decision is used, Democratic appointees show a degree of ideological voting on mixed panels; when the party of the current administration is used, Democratic appointees show no such tendency. But when a political appointee of either party sits on a politically unified panel, her rate of liberal voting exhibits a strong ideological tendency.

Third, the panel effects on liberal voting rates are generally well ordered, in the sense that the patterns are in line with those observed in many areas of the law. ${ }^{42}$ An exception is the behavior of Republican appointees on panels including one or instead two Democratic appointees. Usually judges show a "collegial concurrence," in accordance with which Republican appointees display relatively liberal voting patterns when sitting with two Democratic appointees, and Democratic appointees display fairly conservative voting patterns when sitting with two Republican appointees. ${ }^{43}$ And indeed this is the pattern we observe in Figure 4 for Democratic appointees in EPA cases and Republican appointees in NLRB cases. But in the data as a whole, and in EPA cases, Republican appointees show the same rate of liberal voting regardless of whether they are sitting with one or two Democratic appointees.

\footnotetext{
42 See Sunstein, Schkade, and Ellman, 90 Va L Rev at 316-18 (cited in note 35).

43 See id.
} 


\section{FIGURE 4}

Liberal Voting Rates of Circuit Judges in Chevron Cases, by Panel Composition, Agency, and Party of Appointing President

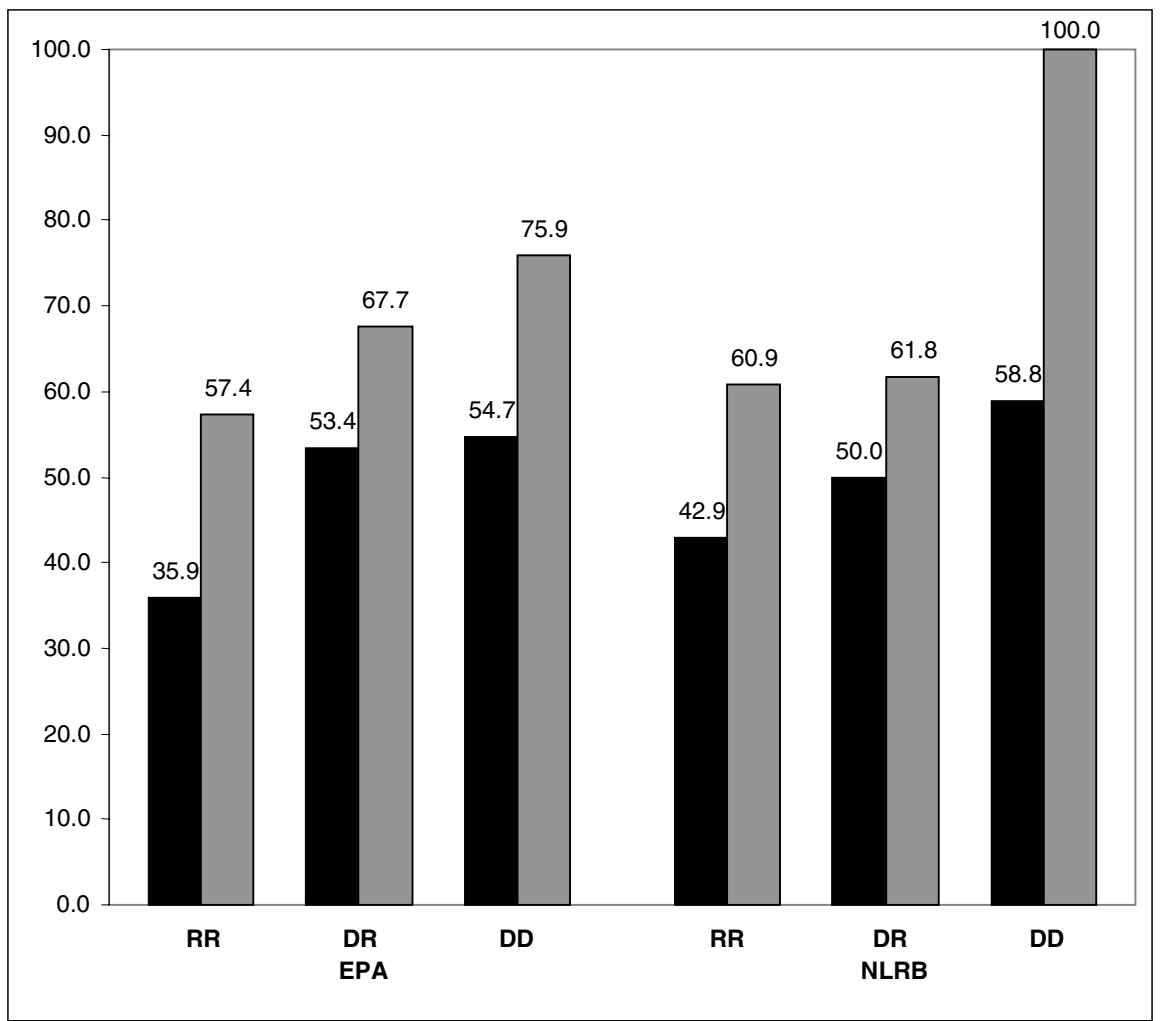

Note: The darkly shaded bars indicate the validation rates of Republican appointees, and the lightly shaded bars indicate the validation rates of Democratic appointees.

Similarly, Democratic appointees in NLRB cases show nearly the same rate of liberal voting regardless of whether they sit with one or two Republican appointees. The most obvious explanation for this unusual finding is that Republican appointees in EPA cases and Democratic appointees in NLRB cases have strong convictions, so that they are willing to dissent from two colleagues from the other party. Note, however, that the behavior of appointees in general is hardly impervious to panel influences; there is a very large difference between their voting patterns on unified and mixed panels.

Fourth, the partisan composition of the panel seems to have little influence on the overall rate of validation for both Democratic and Republican appointees. But this appearance obscures stronger ideological patterns that emerge in finer decompositions of the data. In particular, when validation rates are broken out by the political con- 
tent of the agency decision, panel composition appears to have a strong influence on the degree of ideological voting. In Figure 2, the overall validation rates of Republican appointees change little with the composition of the panel, and those of Democratic appointees move only slightly, except when they sit on a politically unified panel. Yet when the political content of the agency decision is considered, as in Tables 9 and 12, the validation rates of unified panels show strong ideological propensities. The pattern is analogous to Table 7, where similar overall rates of validation by Republican and Democratic appointees masked pronounced ideological voting that became apparent when the data were stratified according to the political content of the agency decision.

If this admittedly complex evidence is taken as a whole, it does show that ideological voting is dampened, even if not eliminated, on politically mixed panels. Although the data do not establish that Chevron itself is responsible for this compression in ideological voting in validation rates, they do raise this as a serious possibility.

\section{IMPLICATIONS}

A. Of Interpretation and Policymaking

What are the implications of these findings? At first glance, the evidence seems to fortify the argument for a strong reading of Chevron. There is no reason to think that where statutes are ambiguous, their meaning should depend on the composition of the panel that litigants draw, or on the ideological predilections of the sitting judges. If the resolution of statutory ambiguities turns on judgments of policy, then those judgments ought to be made by the relevant agencies, not by federal courts.

To understand this claim, it is important to return to the rationale of Chevron itself. Strikingly, the Court did not justify its two-step inquiry by reference to the language or history of the Administrative Procedure Act. Instead the Court referred to two pragmatic points: judges lack expertise and they are not politically accountable. In interpreting law, the agency may "properly rely upon the incumbent administration's views of wise policy to inform its judgments. While agencies are not directly accountable to the people, the Chief Executive is." "In the Court's view, it would be appropriate for agencies operating under the Chief Executive, rather than judges, to resolve "competing interests which Congress itself either inadvertently did not resolve, or intentionally left to be resolved ... in light of everyday realities."

44 Chevron, 467 US at 865.

45 Id at $865-66$. 
What is most striking about this passage is the explicit suggestion that resolution of statutory ambiguities requires a judgment about resolving "competing interests."

Building on these ideas, the most forceful defenses of Chevron have insisted on two points. The first is that the resolution of statutory ambiguities calls for a judgment of policy-one that should be made by executive officials rather than by judges. ${ }^{46}$ The judgment of policy might be informed by technical expertise, as, for example, when the agency is entrusted with applying its specialized competence to disputed areas. Alternatively, the judgment might be purely normative, as, for example, in the view that in the face of uncertainty, statutes should be construed so as to fit with the outcome of cost-benefit analysis ${ }^{47}$ or to protect public health. ${ }^{48}$ Whether specialized competence or judgments of value are involved, agencies have a strong comparative advantage over courts, and deference is therefore the appropriate rule.

The second point is that the Supreme Court should adopt rules of deference that counteract the potential balkanization of federal law. This problem is likely to emerge if different courts of appeals, with their different predilections, approach agency interpretations in an independent fashion. ${ }^{49}$ In the abstract, Chevron should reduce the risk of balkanization simply because judges have been instructed to defer to reasonable interpretations of ambiguous terms. And indeed an obvious defense of Chevron's deference principle is that it decreases the risk that similarly situated litigants will produce different substantive law merely because of policy disagreements among lower court judges.

How does the evidence explored here bear on these questions? At first glance, it emphatically supports the view that resolution of ambiguities often calls for judgments of policy. The difference between Republican and Democratic appointees is simply not explicable in

46 See E. Donald Elliott, Chevron Matters: How the Chevron Doctrine Redefined the Roles of Congress, Courts and Agencies in Environmental Law, 16 Vill Envir L J 1, 14 (2005) ("[I]t is neither a legislative nor judicial function, but rather an executive function for an agency, acting under presidential supervision, to answer statutory questions left open by Congress.").

47 See Executive Order 12291, 3 CFR § 2(c)-(d) (1981) (ordering that "[r]egulatory objectives shall be chosen to maximize the net benefits to society" and that "[a]mong alternative approaches to any given regulatory objective, the alternative involving the least net cost to society shall be chosen").

48 This is one reading of the FDA's judgment in FDA v Brown \& Williamson Tobacco Corp, 529 US 120 (2000) (invalidating FDA regulations of tobacco promulgated after the FDA determined that nicotine was a "drug" under the Food, Drug, and Cosmetic Act). "The agency believed that, because most tobacco consumers begin their use before reaching the age of 18 , curbing tobacco use by minors could substantially reduce the prevalence of addiction in future generations and thus the incidence of tobacco-related death and disease." Id at 125.

49 See Strauss, 87 Colum L Rev at 1121-22 (cited in note 8) (arguing that Chevron prevents balkanization by directing that ambiguous statutes be interpreted by one agency rather than courts in twelve circuits). 
other terms. Within the Supreme Court, Chevron may or may not have reduced the role of policy disagreement in judicial review of agency interpretations of law. Unfortunately, its success on that count has been at best partial, both within the Supreme Court and among the lower courts. For this reason, it appears that federal judges have not taken Chevron seriously enough.

At the same time, there is a continuing risk of balkanization of federal law, if only because different panels will predictably arrive at different results on the same questions, which by hypothesis involve judgments of policy rather than law. In the abstract, those questions should be answered by those with technical expertise or political accountability. They should not be answered by federal judges. In short, the evidence seems to suggest the need for courts to adhere more closely to the Chevron framework, so as to reduce the risk that regulatory law will reflect the preferences of the relevant panel.

The evidence explored here also has jurisprudential implications. Consider, for example, Ronald Dworkin's influential account of law as "integrity." Dworkin contends that interpretation, including statutory interpretation, ${ }^{52}$ requires a judgment about "fit" with existing materials and about "justification" of those materials; his conception of law as integrity requires judges to put existing materials in their "best constructive light." "Where "fit" leaves more than one possibility, judges have a degree of discretion. Everyone should agree that the executive, no less than the judiciary, has a duty of "fit"; many of the hard cases arise when the key question is which interpretation puts the law in its "best constructive light."

But-and here is a question Dworkin does not ask - why should courts be entrusted with the duty to carry out that task? In modern government, courts are often less capable on that count than is the executive, precisely because of its comparatively greater expertise and accountability. In deciding how to understand the Endangered Species Act, the Food and Drug Act, and the Clean Air Act, it would be puzzling to suggest that courts are in a particularly good position to identify the "best constructive light." The suggestion would be especially puzzling if it turned out that Republican and Democratic nominees

50 Of course resolution of some ambiguities does depend on judgments of law. The only claim made here, in the spirit of Chevron itself, is that where a statute is genuinely ambiguous, a judgment of policy is inevitable. We do not attempt to unpack the complexities of "genuine ambiguity" necessary to a full analysis of Chevron Step One. The data presented here strongly suggest that policy judgments operate in the real-world operation of that step.

51 See generally Ronald Dworkin, Law's Empire (Belknap 1986).

52 See id at 313-54.

53 See generally id. 
systematically differed in their judgments about what the "best constructive light" reveals. If statutory interpretation often involves an element of policymaking discretion-and the evidence so suggeststhe argument for a strong reading of Chevron is surely strengthened.

Nothing that we have said resolves the dispute over textualism in statutory interpretation. Suppose, plausibly, that some of our results are attributable to the fact that some judges follow "plain meaning" whereas others do not; suppose, also plausibly, that some of our results are driven by different attitudes toward bureaucracies in general. To the extent that judges differ on these questions, differences in the application of the Chevron framework are inevitable. At a minimum, however, we can suggest that to the extent that the differences are rooted in political considerations, Chevron would best be implemented in a way that dampens the role of those considerations.

\section{B. Tempting Counterarguments}

1. Of lags and politics.

An initial response would suggest that the evidence does not, in fact, support a decision to give greater discretionary authority to regulatory agencies. The response would have two components. First, a relatively strong judicial role reduces the power of an incumbent president to make many changes in a short period-it helps to stabilize the law. Second, a strong judicial role is not adequately characterized as a substitution of judicial judgment for executive judgments. If the evidence is taken seriously, then a strong judicial role operates instead to extend the policymaking reach of a previous president. When Clinton appointees take a strong hand against executive decisions in the Bush Administration, or when Justices Scalia and Thomas take a strong hand against the Clinton Administration, the views of an earlier president are being given continuing authority. In the abstract, it is not clear that this continuing authority is undesirable.

Insofar as this response emphasizes stability, it is not on strong ground, simply because administrative law already ensures a high degree, and perhaps an excessively high degree, of stability. It is both time consuming and difficult to make a regulation; often the process takes two years or more. ${ }^{54}$ To say the least, new presidents cannot immediately change agency policy as they see fit. The "ossification" of rulemaking is a familiar problem in administrative law. The additional

\footnotetext{
54 Consider Stephen G. Breyer, et al, Administrative Law and Regulatory Policy: Problems, Text, and Cases 731 (Aspen 5th ed 2002).

55 See generally Thomas O. McGarity, Some Thoughts on "Deossifying" the Rulemaking Process, 41 Duke L J 1385 (1992) (discussing the causes of and potential solutions to the problem
} 
delay that comes from the exercise of judicial policymaking authority-by appointees of presidents who are no longer in office-hardly seems desirable. Indeed, that delay is a singularly odd way to slow down executive decisions, because it depends on the (random) draw of judges who are unsympathetic to the incumbent president on policy grounds.

The response is more interesting insofar as it emphasizes the evident fact that previous presidents are able to play a role in "freezing" executive policy. The evidence clearly shows that presidential appointments have a continuing effect on regulatory policy insofar as judges are sometimes skeptical of the policy initiatives of their successors. But why is this desirable? If the Bush Administration is embarking on a new policy in the domain of environmental protection or telecommunications, does it really make sense to say that it should be "checked" by the policy preferences of judicial appointees of President Clinton? Unless the Bush Administration is violating the law or acting arbitrarily, an affirmative answer is difficult to defend. To the extent that the policy preferences of judicial appointees are driving judicial decisions, there seems to be little to say on behalf of the existing situation.

2. The inevitability of politics.

A different response would suggest that whatever the strength of the deference rule, political differences will break out on the margin along which litigation occurs. Of course Republican appointees and Democratic appointees would agree if the rule of deference were absolute-if judges were told that agency interpretations of law must be upheld under all circumstances. But so long as there is some room for review, political differences will matter at the point where that review occurs. If, for example, the agency must be upheld unless the statute is entirely without ambiguity, then litigants will challenge agency action only when the statute is (arguably) entirely without ambiguity, and then agencies will interpret statutes aggressively in their preferred directions. In the hard cases that ultimately arise, Democratic appointees will disagree with Republican appointees in just the ways that we have outlined here.

This conjecture cannot be ruled out of bounds. Under the current version of Chevron, political differences play a substantial role; under

of “ossification”); Jerry L. Mashaw and David L. Harfst, The Struggle for Auto Safety 9-25 (Harvard 1990) (discussing the decline in rulemaking activity by the National Highway Traffic Safety Administration and attributing it to "the inertial force of the general political and legal culture within which [the] regulatory regime [is] constructed and operated"). 
a stronger version of Chevron, perhaps the data would look essentially identical.

Suppose that the conjecture is right. Even if so, that stronger version would reflect a large-scale allocation of interpretive authority to the executive, simply because the executive's interpretive discretion would be increased. In the remaining cases in which that discretion is subject to reasonable challenge, any political disagreement between the two sets of judges will certainly be tolerable. The broadest point is that if courts endorsed a strong view of the agency's power of interpretation, there would necessarily be a shift in interpretive power from courts to the executive, and the rate of political disagreement among judges should be reduced even if not eliminated.

\section{CONCLUSION}

In its actual application, the Chevron framework shows a large influence from the political convictions of federal judges. Of course judges follow the law. But on the Supreme Court, disagreements about the legality of agency interpretations have an uncomfortable political component, simply because those disagreements often operate along political lines. We have seen that the most conservative members of the Court have been significantly more likely to uphold agency decisions under the two Bush Administrations than under the Clinton Administration-and that the most liberal members of the Court show the opposite tendency. We have also seen that under the Chevron framework, the liberal justices are more likely to uphold liberal agency interpretations than conservative ones-and the conservative justices show the opposite tendency.

On the courts of appeals, a rough equivalence in the overall validation rates of Democratic and Republican appointees obscures dramatic differences in their propensities to validate. These differences emerge when the political content of agency decisions and the composition of appellate panels are considered. Democratic appointees are more likely to uphold liberal decisions than conservative decisions by 23 percentage points, and Republican appointees are more likely to uphold conservative decisions than liberal decisions by 11 percentage points. The differences are still greater and perhaps most disturbing when the composition of the panel is also examined. A Democratic appointee, sitting with two Democratic appointees, is more likely to vote to uphold a liberal decision than a conservative one by more than 30 percentage points - and a Republican appointee, sitting with two Re- 
publican appointees, is more likely to vote to uphold a conservative decision than a liberal one by more than 40 percentage points.

Of course the normative questions are complex and contested, and they have been explored only briefly here. ${ }^{56}$ But however those questions are resolved, the empirical evidence is clear. Notwithstanding Chevron, the political convictions of federal judges are continuing to play a large role in judicial review of agency interpretations of law.

56 For a discussion, see Cass R. Sunstein, Beyond Marbury: The Executive Power to Say What the Law Is, Yale L J (forthcoming 2006). 


\section{APPENDIX: COMPARING JUSTICES ON THE SUPREME COURT}

\section{APPENDIX TABLE 1}

Voting Rates of Individual Supreme Court Justices

(Means, Standard Errors in Parentheses, and Number of Observations in Brackets)

\section{A. Justice Stevens}

\section{Overall}

\begin{tabular}{llcc}
\hline & \multicolumn{3}{l}{ Court Applied Chevron? } \\
\cline { 2 - 4 } Type of Vote & Yes & No & Difference of \\
\hline Voted to Validate & $(1)$ & $(2)$ & $(1)-(2):$ \\
& .710 & .800 & $\mathbf{. 0 9 0}$ \\
& $(.055)$ & $(.107)$ & $\mathbf{( . 1 2 8 )}$ \\
\hline
\end{tabular}

\section{By Party of Current President and Chevron Status}

\begin{tabular}{lccc}
\hline & \multicolumn{3}{c}{ Party of Current President } \\
\cline { 2 - 4 } Type of Vote & $\begin{array}{c}\text { Democratic } \\
(1)\end{array}$ & $\begin{array}{c}\text { Republican } \\
(2)\end{array}$ & $\begin{array}{c}\text { Difference of } \\
(1)-(2):\end{array}$ \\
\hline (A) Voted to Apply & .829 & .796 & $\mathbf{. 0 3 3}$ \\
Chevron & $(.065)$ & $(.058)$ & $\mathbf{( . 0 8 8 )}$ \\
& {$[35]$} & {$[49]$} & \\
(B) Voted to Validate & .806 & .632 & $\mathbf{. 1 7 5}$ \\
When the Court & $(.072)$ & $.079)$ & $\mathbf{( . 1 0 9 )}$ \\
Applied Chevron & {$[31]$} & {$[38]$} & \\
\hline
\end{tabular}

III. By Ideological Content of Agency Decision

\begin{tabular}{lccc}
\hline & \multicolumn{3}{c}{ Ideological Content of Agency Decision } \\
\cline { 2 - 4 } Type of Vote & $\begin{array}{c}\text { Liberal } \\
(1)\end{array}$ & $\begin{array}{c}\text { Not Liberal } \\
(2)\end{array}$ & $\begin{array}{c}\text { Difference of } \\
(1)-(2):\end{array}$ \\
\hline (A) Voted to Apply & .846 & .750 & $\mathbf{. 0 9 6}$ \\
Chevron & $(.051)$ & $(.078)$ & $\mathbf{( . 0 8 9 )}$ \\
& {$[52]$} & {$[32]$} & \\
(B) Voted to Validate & .860 & .462 & $\mathbf{. 3 9 9 * *}$ \\
When the Court & $(.053)$ & $(.100)$ & $\mathbf{( . 1 0 3 )}$ \\
Applied Chevron & {$[43]$} & {$[26]$} &
\end{tabular}

Note: * denotes difference significant at 10 percent level, and ** denotes difference significant at 5 percent level. Differences may not match exactly due to rounding. 


\section{APPENDIX TABLE 1 (cont.)}

\section{Voting Rates of Individual Supreme Court Justices} (Means, Standard Errors in Parentheses, and Number of Observations in Brackets)

\section{B. Justice Souter}

I. Overall

\begin{tabular}{llcc}
\hline & \multicolumn{3}{l}{ Court Applied Chevron? } \\
\cline { 2 - 4 } Type of Vote & Yes & No & Difference of \\
\hline Voted to Validate & $(1)$ & $(2)$ & $\mathbf{. 1 2 8}$ \\
& .770 & .643 & $\mathbf{( . 1 3 0 )}$ \\
\hline
\end{tabular}

\section{By Party of Current President and Chevron Status}

\begin{tabular}{lccc}
\hline & \multicolumn{3}{c}{ Party of Current President } \\
\cline { 2 - 4 } Type of Vote & $\begin{array}{c}\text { Democratic } \\
(1)\end{array}$ & $\begin{array}{c}\text { Republican } \\
(2)\end{array}$ & $\begin{array}{c}\text { Difference of } \\
(1)-(2):\end{array}$ \\
\hline (A) Voted to Apply & .857 & .750 & $\mathbf{. 1 0 7}$ \\
Chevron & $(.060)$ & $(.070)$ & $\mathbf{( . 0 9 3 )}$ \\
& {$[35]$} & {$[40]$} & \\
(B) Voted to Validate & .774 & .767 & $\mathbf{. 0 0 8}$ \\
When the Court & $(.076)$ & $.079)$ & $\mathbf{( . 1 1 0 )}$ \\
Applied Chevron & {$[31]$} & {$[30]$} & \\
\hline
\end{tabular}

III. By Ideological Content of Agency Decision

\begin{tabular}{lccc}
\hline & \multicolumn{3}{c}{ Ideological Content of Agency Decision } \\
\cline { 2 - 4 } Type of Vote & $\begin{array}{c}\text { Liberal } \\
(1)\end{array}$ & $\begin{array}{c}\text { Not Liberal } \\
(2)\end{array}$ & $\begin{array}{c}\text { Difference of } \\
(1)-(2):\end{array}$ \\
\hline (A) Voted to Apply & .792 & .815 & $\mathbf{. 0 2 3}$ \\
Chevron & $(.059)$ & $(.076)$ & $\mathbf{( . 0 9 7 )}$ \\
& {$[48]$} & {$[27]$} & \\
(B) Voted to Validate & .821 & .682 & $\mathbf{. 1 3 9}$ \\
When the Court & $(.062)$ & $(.102)$ & $\mathbf{( . 1 1 3}$ \\
Applied Chevron & {$[39]$} & {$[22]$} &
\end{tabular}

Note: * denotes difference significant at 10 percent level, and ** denotes difference significant at 5 percent level. Differences may not match exactly due to rounding. 
APPENDIX TABLE 1 (cont.)

Voting Rates of Individual Supreme Court Justices

(Means, Standard Errors in Parentheses, and Number of Observations in Brackets)

\section{Justice Breyer}

\section{Overall}

\begin{tabular}{lccc}
\hline & \multicolumn{3}{c}{ Court Applied Chevron? } \\
\cline { 2 - 4 } Type of Vote & Yes & No & Difference of \\
& $(1)$ & $(2)$ & $(1)-(2):$ \\
\hline Voted to Validate & .818 & .900 & $\mathbf{. 0 8 2}$ \\
& $(.059)$ & $(.100)$ & $\mathbf{( . 1 3 3 )}$ \\
\hline
\end{tabular}

\section{By Party of Current President and Chevron Status}

\begin{tabular}{lccc}
\hline & \multicolumn{3}{c}{ Party of Current President } \\
\cline { 2 - 4 } Type of Vote & $\begin{array}{c}\text { Democratic } \\
\text { Republican }\end{array}$ & $\begin{array}{c}\text { Difference of } \\
(1)-(2):\end{array}$ \\
\hline (A) Voted to Apply & .852 & $(2)$ & $\mathbf{. 0 7 4}$ \\
Chevron & $(.070)$ & $(.082)$ & $\mathbf{( . 1 0 7 )}$ \\
& {$[27]$} & {$[27]$} & \\
(B) Voted to Validate & .833 & .800 & $\mathbf{. 0 3 3}$ \\
When the Court & $(.078)$ & $(.092)$ & $\mathbf{( . 1 1 9 )}$ \\
Applied Chevron & {$[24]$} & {$[20]$} & \\
& & & \\
\hline
\end{tabular}

\section{By Ideological Content of Agency Decision}

\begin{tabular}{lccc}
\hline & \multicolumn{3}{c}{ Ideological Content of Agency Decision } \\
\cline { 2 - 4 } Type of Vote & $\begin{array}{l}\text { Liberal } \\
(1)\end{array}$ & $\begin{array}{c}\text { Not Liberal } \\
(2)\end{array}$ & $\begin{array}{c}\text { Difference of } \\
(1)-(2):\end{array}$ \\
\hline (A) Voted to Apply & .838 & .765 & $\mathbf{. 0 7 3}$ \\
Chevron & $(.061)$ & $(.107)$ & $\mathbf{( . 1 1 6 )}$ \\
& {$[37]$} & {$[17]$} & \\
(B) Voted to Validate & .900 & .643 & $\mathbf{. 2 5 7 * *}$ \\
When the Court & $(.056)$ & $(.133)$ & $\mathbf{( . 1 2 9 )}$ \\
Applied Chevron & {$[30]$} & {$[14]$} &
\end{tabular}

Note: * denotes difference significant at 10 percent level, and ** denotes difference significant at 5 percent level. Differences may not match exactly due to rounding. 


\section{APPENDIX TABLE 1 (cont.)}

Voting Rates of Individual Supreme Court Justices (Means, Standard Errors in Parentheses, and Number of Observations in Brackets)

\section{Justice Ginsburg}

\section{Overall}

\begin{tabular}{llcc}
\hline & \multicolumn{3}{c}{ Court Applied Chevron? } \\
\cline { 2 - 4 } Type of Vote & Yes & No & Difference of \\
\hline Voted to Validate & $(1)$ & $(2)$ & $\mathbf{- . 1 6 0}$ \\
& .740 & .900 & $\mathbf{( . 1 4 8 )}$ \\
\hline
\end{tabular}

\section{By Party of Current President and Chevron Status}

\begin{tabular}{lccc}
\hline & \multicolumn{3}{c}{ Party of Current President } \\
\cline { 2 - 4 } Type of Vote & $\begin{array}{c}\text { Democratic } \\
\text { (A) Voted to Apply }\end{array}$ & $\begin{array}{c}\text { Republican } \\
(1)\end{array}$ & $\begin{array}{c}\text { Difference of } \\
(1)-(2):\end{array}$ \\
Chevron & .906 & .750 & $\mathbf{. 1 5 6}$ \\
& $(.052)$ & $(.083)$ & $\mathbf{( . 0 9 6 )}$ \\
(B) Voted to Validate & {$[32]$} & {$[28]$} & \\
When the Court & .724 & .762 & $\mathbf{. 0 3 8}$ \\
Applied Chevron & $(.084)$ & $(.095)$ & $\mathbf{( . 1 2 8 )}$ \\
& {$[29]$} & {$[21]$} & \\
\hline
\end{tabular}

III. By Ideological Content of Agency Decision

\begin{tabular}{lccc}
\hline & \multicolumn{3}{c}{ Ideological Content of Agency Decision } \\
\cline { 2 - 4 } Type of Vote & $\begin{array}{c}\text { Liberal } \\
(1)\end{array}$ & $\begin{array}{c}\text { Not Liberal } \\
(2)\end{array}$ & $\begin{array}{c}\text { Difference of } \\
(1)-(2):\end{array}$ \\
\hline (A) Voted to Apply & .850 & .800 & $\mathbf{. 0 5 0}$ \\
Chevron & $(.057)$ & $(.092)$ & $\mathbf{( . 1 0 4 )}$ \\
& {$[40]$} & {$[20]$} & \\
(B) Voted to Validate & 0.818 & .588 & $\mathbf{. 2 3 0}$ \\
When the Court & $(.068)$ & $(.123)$ & $\mathbf{( . 1 2 9}$ \\
Applied Chevron & {$[33]$} & {$[17]$} &
\end{tabular}

Note: * denotes difference significant at 10 percent level, and ** denotes difference significant at 5 percent level. Differences may not match exactly due to rounding. 
APPENDIX TABLE 1 (cont.)

Voting Rates of Individual Supreme Court Justices

(Means, Standard Errors in Parentheses, and Number of Observations in Brackets)

\section{E. Justice O'Connor}

\begin{tabular}{llcc}
\multicolumn{4}{c}{ I. Overall } \\
\hline \\
\cline { 2 - 4 } Court Applied Chevron? & \\
\cline { 2 - 4 } Type of Vote & Yes & No & Difference of \\
\hline Voted to Validate & $(1)$ & $(2)$ & $(1)-(2):$ \\
& .677 & .333 & $\mathbf{. 3 4 *} * *$ \\
& $(.058)$ & $(.126)$ & \\
\hline
\end{tabular}

\section{By Party of Current President and Chevron Status}

\begin{tabular}{lccc}
\hline & \multicolumn{3}{c}{ Party of Current President } \\
\cline { 2 - 4 } Type of Vote & $\begin{array}{c}\text { Democratic } \\
(1)\end{array}$ & $\begin{array}{c}\text { Republican } \\
(2)\end{array}$ & $\begin{array}{c}\text { Difference of } \\
(1)-(2):\end{array}$ \\
\hline (A) Voted to Apply & .727 & .745 & $\mathbf{- . 0 1 7}$ \\
Chevron & $(.079)$ & $(.064)$ & $\mathbf{( . 1 0 1 )}$ \\
& {$[33]$} & {$[47]$} & \\
(B) Voted to Validate & .655 & .694 & $\mathbf{- . 0 3 9}$ \\
When the Court & $(.090)$ & $.078)$ & $\mathbf{( . 1 1 8 )}$ \\
Applied Chevron & {$[29]$} & {$[36]$} & \\
\hline
\end{tabular}

III. By Ideological Content of Agency Decision

\begin{tabular}{lccc}
\hline & \multicolumn{3}{c}{ Ideological Content of Agency Decision } \\
\cline { 2 - 4 } Type of Vote & $\begin{array}{c}\text { Liberal } \\
(1)\end{array}$ & $\begin{array}{c}\text { Not Liberal } \\
(2)\end{array}$ & $\begin{array}{c}\text { Difference of } \\
(1)-(2):\end{array}$ \\
\hline (A) Voted to Apply & .714 & .774 & $\mathbf{. 0 6 0}$ \\
Chevron & $(.065)$ & $(.076)$ & $\mathbf{( . 1 0 2 )}$ \\
& {$[49]$} & {$[31]$} & \\
(B) Voted to Validate & .625 & .760 & $\mathbf{- . 1 3 5}$ \\
When the Court & $. .078)$ & $(.087)$ & $\mathbf{( . 1 2 0 )}$ \\
Applied Chevron & {$[40]$} & {$[25]$} &
\end{tabular}

Note: * denotes difference significant at 10 percent level, and ** denotes difference significant at 5 percent level. Differences may not match exactly due to rounding. 


\section{APPENDIX TABLE 1 (cont.)}

Voting Rates of Individual Supreme Court Justices (Means, Standard Errors in Parentheses, and Number of Observations in Brackets)

\section{F. Justice Kennedy}

\section{Overall}

\begin{tabular}{llcc}
\hline & \multicolumn{3}{l}{ Court Applied Chevron? } \\
\cline { 2 - 4 } Type of Vote & Yes & No & Difference of \\
& $(1)$ & $(2)$ & $(1)-(2):$ \\
\hline Voted to Validate & .672 & .400 & $\mathbf{. 2 7 2 * *}$ \\
& $(.058)$ & $(.131)$ & $\mathbf{( . 1 3 7 )}$ \\
\hline
\end{tabular}

\section{By Party of Current President and Chevron Status}

\begin{tabular}{lccc}
\hline & \multicolumn{3}{c}{ Party of Current President } \\
\cline { 2 - 4 } Type of Vote & $\begin{array}{c}\text { Democratic } \\
(1)\end{array}$ & $\begin{array}{c}\text { Republican } \\
(2)\end{array}$ & $\begin{array}{c}\text { Difference of } \\
(1)-(2):\end{array}$ \\
\hline (A) Voted to Apply & .857 & .723 & $\mathbf{. 1 3 4}$ \\
Chevron & $(.060)$ & $(.066)$ & $\mathbf{( . 0 9 2 )}$ \\
& {$[35]$} & {$[47]$} & \\
(B) Voted to Validate & .774 & .583 & $\mathbf{. 1 9 1 *}$ \\
When the Court & $(.076)$ & $.083)$ & $\mathbf{( . 1 1 4 )}$ \\
Applied Chevron & {$[31]$} & {$[36]$} & \\
\hline
\end{tabular}

\section{By Ideological Content of Agency Decision}

\begin{tabular}{lccc}
\hline & \multicolumn{3}{c}{ Ideological Content of Agency Decision } \\
\cline { 2 - 4 } Type of Vote & $\begin{array}{c}\text { Liberal } \\
(1)\end{array}$ & $\begin{array}{c}\text { Not Liberal } \\
(2)\end{array}$ & $\begin{array}{c}\text { Difference of } \\
(1)-(2):\end{array}$ \\
\hline (A) Voted to Apply & .784 & .774 & $\mathbf{. 0 1 0}$ \\
Chevron & $(.058)$ & $(.076)$ & $\mathbf{( . 0 9 5 )}$ \\
& {$[51]$} & {$[31]$} & \\
(B) Voted to Validate & .667 & .680 & $\mathbf{- . 0 1 3}$ \\
When the Court & $(.074)$ & $.095)$ & $\mathbf{( . 1 2 0}$ \\
Applied Chevron & {$[42]$} & {$[25]$} &
\end{tabular}

Note: * denotes difference significant at 10 percent level, and ** denotes difference significant at 5 percent level. Differences may not match exactly due to rounding. 
APPENDIX TABLE 1 (cont.)

Voting Rates of Individual Supreme Court Justices

(Means, Standard Errors in Parentheses, and Number of Observations in Brackets)

G. Justice Rehnquist

\begin{tabular}{llcc}
\multicolumn{4}{c}{ I. Overall } \\
\hline \\
\cline { 2 - 4 } Court Applied Chevron? & \\
Type of Vote & Yes & No & Difference of \\
\hline Voted to Validate & $(1)$ & $(2)$ & $(1)-(2):$ \\
& .638 & .462 & $\mathbf{. 1 7 6}$ \\
& $(.058)$ & $(.144)$ & $\mathbf{( . 1 4 8 )}$ \\
\hline
\end{tabular}

II. By Party of Current President and Chevron Status

\begin{tabular}{lccc}
\hline & \multicolumn{3}{c}{ Party of Current President } \\
\cline { 2 - 4 } Type of Vote & $\begin{array}{c}\text { Democratic } \\
(1)\end{array}$ & $\begin{array}{c}\text { Republican } \\
(2)\end{array}$ & $\begin{array}{c}\text { Difference of } \\
(1)-(2):\end{array}$ \\
\hline (A) Voted to Apply & .800 & .787 & $\mathbf{. 0 1 3}$ \\
Chevron & $(.069)$ & $(.060)$ & $\mathbf{( . 0 9 2 )}$ \\
& {$[35]$} & {$[47]$} & \\
(B) Voted to Validate & .516 & .737 & $\mathbf{. . 2 2 1 *}$ \\
When the Court & $(.091)$ & $.072)$ & $\mathbf{( . 1 1 5 )}$ \\
Applied Chevron & {$[31]$} & {$[38]$} & \\
\hline
\end{tabular}

III. By Ideological Content of Agency Decision

\begin{tabular}{lccc}
\hline & \multicolumn{3}{c}{ Ideological Content of Agency Decision } \\
\cline { 2 - 4 } Type of Vote & $\begin{array}{c}\text { Liberal } \\
(1)\end{array}$ & $\begin{array}{c}\text { Not Liberal } \\
(2)\end{array}$ & $\begin{array}{c}\text { Difference of } \\
(1)-(2):\end{array}$ \\
\hline (A) Voted to Apply & .765 & .839 & $\mathbf{. 0 7 4}$ \\
Chevron & $(.060)$ & $(.067)$ & $\mathbf{( . 0 9 3 )}$ \\
& {$[51]$} & {$[31]$} & \\
(B) Voted to Validate & .558 & .769 & $\mathbf{. . 2 1 1 *}$ \\
When the Court & $(.077)$ & $(.084)$ & $\mathbf{( . 1 1 8 )}$ \\
Applied Chevron & {$[43]$} & {$[26]$} &
\end{tabular}

Note: * denotes difference significant at 10 percent level, and ** denotes difference significant at 5 percent level. Differences may not match exactly due to rounding. 


\section{APPENDIX TABLE 1 (cont.)}

\section{Voting Rates of Individual Supreme Court Justices} (Means, Standard Errors in Parentheses, and Number of Observations in Brackets)

\section{H. Justice Scalia}

I. Overall

\begin{tabular}{llcc}
\hline & \multicolumn{3}{c}{ Court Applied Chevron? } \\
\cline { 2 - 4 } Type of Vote & Yes & No & Difference of \\
\hline Voted to Validate & $(1)$ & $(2)$ & $(1)-(2):$ \\
& .522 & .467 & $\mathbf{. 0 5 5}$ \\
& $(.061)$ & $(.133)$ & $\mathbf{( . 1 4 4 )}$ \\
\hline
\end{tabular}

\section{By Party of Current President and Chevron Status}

\begin{tabular}{lccc}
\hline & \multicolumn{3}{c}{ Party of Current President } \\
\cline { 2 - 4 } Type of Vote & $\begin{array}{c}\text { Democratic } \\
\text { (A) Voted to Apply }\end{array}$ & $\begin{array}{c}\text { Republican } \\
(1)\end{array}$ & $\begin{array}{c}\text { Difference of } \\
(1)-(2):\end{array}$ \\
Chevron & .800 & .837 & $\mathbf{- . 0 3 7}$ \\
& $(.069)$ & $(.053)$ & $\mathbf{( . )}$ \\
(B) Voted to Validate & {$[35]$} & {$[49]$} & \\
When the Court & .419 & .605 & $\mathbf{. 1 8 6}$ \\
Applied Chevron & $(.090)$ & $(.080)$ & $\mathbf{( . 1 2 1 )}$ \\
& {$[31]$} & {$[38]$} & \\
\hline
\end{tabular}

III. By Ideological Content of Agency Decision

\begin{tabular}{lccc}
\hline & \multicolumn{3}{c}{ Ideological Content of Agency Decision } \\
\cline { 2 - 4 } Type of Vote & $\begin{array}{c}\text { Liberal } \\
(1)\end{array}$ & $\begin{array}{c}\text { Not Liberal } \\
(2)\end{array}$ & $\begin{array}{c}\text { Difference of } \\
(1)-(2):\end{array}$ \\
\hline (A) Voted to Apply & .808 & .844 & $\mathbf{. 0 3 6}$ \\
Chevron & $(.055)$ & $(.065)$ & $\mathbf{( . 0 8 7 )}$ \\
& {$[52]$} & {$[32]$} & \\
(B) Voted to Validate & .419 & .692 & $\mathbf{. . 2 7 3} * *$ \\
When the Court & $(.076)$ & $(.092)$ & $\mathbf{( . 1 2 1 )}$ \\
Applied Chevron & {$[43]$} & {$[26]$} &
\end{tabular}

Note: * denotes difference significant at 10 percent level, and ** denotes difference significant at 5 percent level. Differences may not match exactly due to rounding. 
APPENDIX TABLE 1 (cont.)

Voting Rates of Individual Supreme Court Justices

(Means, Standard Errors in Parentheses, and Number of Observations in Brackets)

\section{Justice Thomas}

\begin{tabular}{llcc}
\multicolumn{4}{c}{ I. Overall } \\
\hline
\end{tabular}

II. By Party of Current President and Chevron Status

\begin{tabular}{lccc}
\hline & \multicolumn{3}{c}{ Party of Current President } \\
\cline { 2 - 4 } Type of Vote & $\begin{array}{c}\text { Democratic } \\
(1)\end{array}$ & $\begin{array}{c}\text { Republican } \\
(2)\end{array}$ & $\begin{array}{c}\text { Difference of } \\
(1)-(2):\end{array}$ \\
\hline (A) Voted to Apply & .771 & .676 & $\mathbf{. 0 9 5}$ \\
Chevron & $(.072)$ & $(.081)$ & $\mathbf{( . 1 0 9 )}$ \\
& {$[35]$} & {$[34]$} & \\
(B) Voted to Validate & .484 & .600 & $\mathbf{. 1 1 6}$ \\
When the Court & $(.091)$ & $.100)$ & $\mathbf{( . 1 4 3 )}$ \\
Applied Chevron & {$[31]$} & {$[25]$} & \\
\hline
\end{tabular}

III. By Ideological Content of Agency Decision

\begin{tabular}{lccc}
\hline & \multicolumn{3}{c}{ Ideological Content of Agency Decision } \\
\cline { 2 - 4 } Type of Vote & $\begin{array}{c}\text { Liberal } \\
(1)\end{array}$ & $\begin{array}{c}\text { Not Liberal } \\
(2)\end{array}$ & $\begin{array}{c}\text { Difference of } \\
(1)-(2):\end{array}$ \\
\hline (A) Voted to Apply & .689 & .792 & $\mathbf{. 1 0 3}$ \\
Chevron & $(.070)$ & $(.085)$ & $\mathbf{( . 1 1 4 )}$ \\
& {$[45]$} & {$[24]$} & \\
(B) Voted to Validate & .378 & .842 & $\mathbf{- . 4 6 4 * *}$ \\
When the Court & $(.081)$ & $(.086)$ & $\mathbf{( . 1 2 9 )}$ \\
Applied Chevron & {$[37]$} & {$[19]$} &
\end{tabular}

Note: * denotes difference significant at 10 percent level, and ** denotes difference significant at 5 percent level. Differences may not match exactly due to rounding. 


\section{APPENDIX TABLE 2}

Liberal Voting Rates of Supreme Court Justices: by Groups of Justices, by Party of Current President, and by Chevron Status

(Means, Standard Errors in Parentheses, and Number of Observations in Brackets)

\section{Justices Stevens, Souter, Breyer, and Ginsburg}

\begin{tabular}{lccc}
\hline & \multicolumn{3}{c}{ Party of Current President } \\
\cline { 2 - 4 } Type of Analysis & $\begin{array}{c}\text { Democratic } \\
(1)\end{array}$ & $\begin{array}{c}\text { Republican } \\
(2)\end{array}$ & $\begin{array}{c}\text { Difference of } \\
(1)-(2):\end{array}$ \\
\hline (A) Court Applied & .730 & .606 & $\mathbf{. 1 2 5} * *$ \\
Chevron & $(.042)$ & $(.047)$ & $\mathbf{( . 0 6 3 )}$ \\
& {$[115]$} & {$[109]$} & \\
(B) Court Did Not & .786 & .886 & $\mathbf{- . 1 0 0}$ \\
Apply Chevron & $(.114)$ & $(.055)$ & $\mathbf{( . 1 1 2 )}$ \\
& {$[14]$} & {$[35]$} & \\
Difference of (A)-(B): & $\mathbf{. . 0 5 5}$ & $\mathbf{- . 2 8 0 * *}$ & - \\
& $\mathbf{( . 1 2 6 )}$ & $\mathbf{( . 0 8 9 )}$ & \\
\hline
\end{tabular}

\section{Justices Kennedy and O'Connor}

\begin{tabular}{lccc}
\hline & \multicolumn{3}{c}{ Party of Current President } \\
\cline { 2 - 4 } Type of Analysis & $\begin{array}{c}\text { Democratic } \\
(1)\end{array}$ & $\begin{array}{c}\text { Republican } \\
(2)\end{array}$ & $\begin{array}{c}\text { Difference of } \\
(1)-(2):\end{array}$ \\
\hline (A) Court Applied & .567 & .458 & $\mathbf{. 1 0 8}$ \\
Chevron & $(.065)$ & $(.059)$ & $\mathbf{( . 0 8 8 )}$ \\
& {$[60]$} & {$[72]$} & \\
(B) Court Did Not & .375 & .636 & $\mathbf{- . 2 6 1}$ \\
Apply Chevron & $(.183)$ & $(.105)$ & $\mathbf{( . 2 0 6 )}$ \\
& {$[8]$} & {$[22]$} & \\
Difference of (A)-(B): & $\mathbf{. 1 9 2}$ & $\mathbf{- . 1 7 8}$ & -- \\
& $\mathbf{( . 1 8 9 )}$ & $\mathbf{( . 1 2 2}$ & \\
\hline
\end{tabular}

III. Justices Rehnquist, Scalia, and Thomas

\begin{tabular}{lccc}
\hline & \multicolumn{2}{c}{ Party of Current President } & \\
\cline { 2 - 4 } Type of Analysis & Democratic & Republican & Difference of \\
(A) Court Applied & $(1)$ & $(2)$ & $(1)-(2):$ \\
Chevron & .387 & .347 & $\mathbf{. 0 4 1}$ \\
& $(.051)$ & {$[1048)$} & $\mathbf{( . 0 7 0 )}$ \\
(B) Court Did Not & {$[93]$} & .414 & \\
Apply Chevron & .167 & $(.093)$ & $\mathbf{- . 2 4 7}$ \\
& $(.112)$ & {$[29]$} & $\mathbf{( . 1 6 2 )}$ \\
Difference of (A)-(B): & {$[12]$} & $\mathbf{. 0 6 7}$ & \\
& $\mathbf{. 2 2 0}$ & $\mathbf{( . 1 0 2 )}$ & - \\
\hline
\end{tabular}

Note: * denotes difference significant at 10 percent level, and ** denotes difference significant at 5 percent level. Differences may not match exactly due to rounding. 